Allaire B. Stallsmith*

\title{
A Divine Couple: Demeter Malophoros and Zeus Meilichios in Selinus
}

https://doi.org/10.1515/jah-2018-0019

\begin{abstract}
This paper concerns a collection of rough-hewn flat stelae excavated from the precinct of Zeus Meilichios in Selinus, Sicily between 1915 and 1926, a majority with two heads or busts, one male and one female, carved at their tops. These crudely fashioned idols are unique in their iconography. They combine the flat inscribed Punic stela with the Greek figural tradition, with some indigenous features. Their meaning is totally obscure - especially since they lack any literary reference. No comparable monuments have been found in ancient Mediterranean cult. The twin stelae were often set up above a collection of burnt rodent and bird bones, ashes, lamps, broken and burnt pottery and terracotta figurines, as a memorial of a sacrifice. The stelae were the objects of a gentilicial cult, similar to that posited for the inscribed "Meilichios stones" with which they shared the Field of Stelae of Zeus Meilichios. The theory advanced here interprets these diminutive stelae (average height $30 \mathrm{~cm}$ ) as the objects of domestic cult. It was customary in many parts of the ancient Mediterranean, from the Bronze Age down to the Roman period, to venerate household or family gods who protected the health and the wealth of the family. They were thought to embody the spirits of the ancestors and could at times be identified with the gods of the state religion.

This divine couple whose effigies were dedicated in the Field of Stelae over a period of four centuries, into the third century, cannot be claimed as Greek or Punic deities. What these nameless protectors of the family were called we cannot say: Meilichios and Meilichia, Father and Mother, or Lord and Lady of the household? As the objects of such a personal domestic cult, their names might have differed with each family.
\end{abstract}

Keywords: Demeter Malophoros, Zeus Meilichios, Selinus (Sicily), Household Religion, Greek Religion, Punic Religion

*Corresponding author: Allaire B. Stallsmith, Associate Professor Emerita, History Department, Towson University, Towson, MD 21207, E-Mail: astallsmith@towson.edu 


\section{The stelae}

No visitor can fail to be intrigued by the stelae excavated from the precinct of Zeus Meilichios in Selinus, Sicily and artfully displayed in the Archeological Museum “Antonino Salinas" in Palermo. ${ }^{1}$ Almost 100 of these rough-hewn flat stones or carved stelae were found between 1915 and 1926, a majority with two heads, male and female, carved at their tops. ${ }^{2}$ The exhibit (re-installed in 2017), gives the visitor the impression that these twin stelae represent a Greco-Punic cult serving the unnamed god and goddess depicted there, perhaps Demeter Malophoros and Zeus Meilichios, whose sanctuaries nestle so close to each other on Selinus' Gaggera hill.

The two engraved or sculptured heads on the stelae have attracted scholarly attention because of their uniqueness in ancient Greek and Phoenico-Punic iconography. ${ }^{3}$ They combine the flat inscribed Punic stela with the Greek figural tradition, with some features possibly supplied by their indigenous sculptors. Their meaning is totally obscure - especially since they lack any literary reference. No comparable monuments have been found in the orbit of ancient Greek, Phoenician or Punic cult. ${ }^{4}$ There is little agreement among scholars about the cult practiced in the Meilichios precinct, whether it is Greek, Punic or a Greco-Punic syncretism. Nor is there a consensus as to whether the cult changed over the long period of its existence from the seventh to the third century BC.

Although the epithets Malophoros and Meilichios are well known from mainland Greek literary and epigraphical sources, their cults in Selinus are known only from scanty epigraphical evidence. What was Malophoros' relation to Demeter Malophoros of Megara, to Hera, to Persephone or even to Tanit, the Punic goddess worshipped in nearby Motya? Who was Meilichios and how was he related to the Greek cult of Zeus Meilichios, to Hades or to Tanit's consort Ba'al Hammon?

At least three theories have been advanced to explain the twin stelae: First, that they represent the Greek deities Zeus Meilichios and his female partner, named variously Persephone, Pasikrateia, Hera or Meilichia. ${ }^{5}$ Secondly, that they are the generic Mediterranean male and female principles of fertility, known only

1 Grotta (2010), 230 argues that the exhibit is all too intriguing ... and thus misleading.

2 Gabrici (1927), 174-178; Famà and Tusa (2000), 21: $83 \%$ of the stones she catalogs, to be precise.

3 Gabrici (1927), 174-178; Pace (1945); Di Vita (1961-1964); White (1967); Jameson, et al. (1993); Famà and Tusa (2000); Grotta (2010).

4 Little similarity in style can be found between the Selinuntine stelae and those from the Punic world: Jameson, et al. (1993), 104 n. 34. The fourth-century BC two-headed stelae from Panticapaeum are funerary in nature: Posamentir (2010) 304, \# A20.1232.

5 Gabrici (1927), 175-176; di Vita (1961-1964), 237; Famà and Tusa (2000), 77. 
by the vague epithets Malophoros and Meilichios. ${ }^{6}$ Third, that they are syncretized Greco-Punic underworld deities, presiding over a sacrificial site similar in appearance and atmosphere to a Punic tophet. ${ }^{7}$

The theory that I will advance interprets these diminutive stelae (average height $30 \mathrm{~cm}$ ) as the objects of domestic cult. It was customary in many parts of the ancient Mediterranean, from the Bronze Age down to the Roman period, to venerate household or family gods who protected the health and the wealth of the family. They were thought to embody the spirits of the ancestors and could be identified with the gods of the state religion. This study will not, in the end, be able to assign names to the divine couple of the Selinuntine stelae, neither Zeus and Demeter, Hades and Persephone, nor Ba'al and Tanit. The deities of this humble domestic cult, represented by such crudely fashioned effigies, do not have individual names as do the great gods of the civic pantheon. The gods who protect the house and family were simply called "mother" or "father" of the house, "god and goddess of the house" or "Lord" and "Lady."

In what follows I will discuss the historical and archaeological sources as well as the origin and significance of the names of Demeter Malophoros and Zeus Meilichios. The dates, styles and significance of the twin stelae will be discussed as well as other significant finds, such as curse tablets and altars. Grotta's new theory that the twin stelae are late and unidentifiable will be examined and refuted by an examination of the stratigraphy of the Meilichios precinct. Finally, I will present the literary and archaeological evidence for the existence of household or family religion in the Ancient Near East, Canaan/Phoenicia, Israel, Crete, Greece and Rome. I conclude that the twin stelae from Selinus represent a GrecoPunic household cult, the worship of the ancestral god and goddess of the house, which offered an anchor for the ancestral lineages of the settlers in Selinus.

\section{Scholarship on the sanctuary}

Ettore Gabrici, who carried out the first comprehensive investigation of the sanctuary between 1915 and 1926, interpreted the sacred complex on the Gaggera hill as primarily a sanctuary of Demeter Malophoros which included within it the smaller and later precinct of Zeus Meilichios (Fig. 1). New excavations on the Gaggera hill as well as re-examinations of Gabrici's excavation journals have significantly

6 Pace (1945), 473-478.

7 White (1967), 351; V. Tusa (1971); Jameson, et al. (1993), 137-141. The word “tophet” comes from the Hebrew Bible (II Kings 23:10; Isaiah 30:29-33); the Phoenician/Punic word is unknown. 
changed our understanding of the layout of the sanctuary. It has become clear that the sanctuary of Demeter Malophoros was separate from the smaller precinct of Zeus Meilichios. In 1967 White concluded, from a careful examination of the architectural evidence, that the post-409 BC renovation of the temple of Demeter Malophoros and the building of the small temple or naïskos in the northern corner of the precinct of Meilichios were intended to accommodate the cult of the Carthaginian goddess Tanit and her consort Ba'al Hammon. ${ }^{8}$ Beginning in 1969, the "Missione Malophoros" excavations found stelae similar in style, but one-headed, to the west of the naïskos. These were dated to the sixth and fifth century BC by associated pottery. ${ }^{9}$ In 1992 Dewailly further refined the dating and layout of the site. ${ }^{10}$

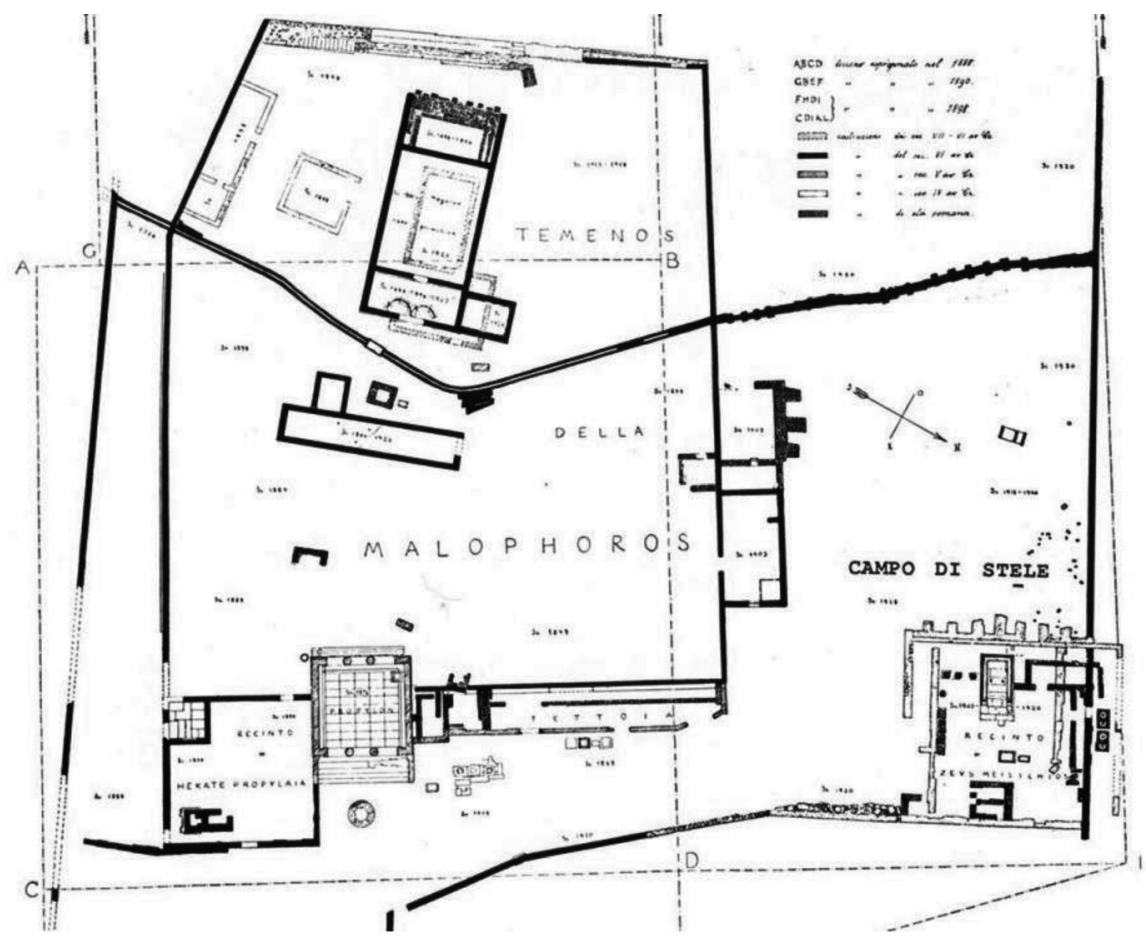

Fig. 1: Plan of the sanctuary area. After Gabrici (1927), Pl. 2.

In their 1993 publication of the Selinuntine lex sacra, Jameson, et al. thoroughly reviewed the evidence about the cult of Zeus Meilichios in the Greek

8 White (1967), 338, 351.

9 S. Tusa, et al. (1984), 5-66; Dehl and Dewailly (1986).

10 Dewailly (1992), 36-37. 
world, and briefly considered the identity of the twin stelae. ${ }^{11}$ In 2000 Famà published a complete catalogue of all the stelae from the precinct of Meilichios. ${ }^{12}$ Most recently, Grotta has made a case for the purely Greek nature of the cult of Zeus Meilichios. He sees the twin stelae as an "archaeological mystery."13

The history of Selinus divides into two phases: the Greek period, from the founding of the city in the seventh century BC until its conquest by Carthage, and the less well-known Punic phase, from 409 BC until its end in the third century $\mathrm{BC}$. The sequence of building and ritual activity on the Gaggera illustrates this change in political hegemony. Likewise, the influence of these two cultures on each other becomes clear in the literary evidence as well as the archaeology.

\section{Selinus: a colony of the "middle ground"}

Even though "colonization" is no longer considered an appropriate term to describe the settlement activities of Greeks and Phoenicians in the Iron Age Mediterranean, the topic itself has generated theories about "Mediterraneanization," ethnic identity formation and "small world" networks. ${ }^{14}$ The conventional view sees Greeks and Phoenicians as establishing distinct and competing "spheres of influence" along the coastal Mediterranean. The Phoenicians, it has been argued, seeking new resources for trade and manufacture, established trading posts with small populations and no territorial ambitions (except for Carthage). The Greek city-states, on the other hand, bursting at the seams with a growing population, founded colonies to provide land for the landless and surpluses of grain for the mother city. ${ }^{15}$

This formulation is contested by historians who note that Phoenician trading posts often controlled a significant extent of hinterland, and who challenge the notion that overpopulation was the universal engine of Greek colonization abroad. ${ }^{16}$ A student of Mediterranean networks has emphasized that Greek and Phoenician colonizing activity cannot be divided into the apoikia, the Greek agricultural settlement, versus the emporion, the Phoenician trading post. ${ }^{17}$

11 Jameson, et al. (1993), 103-107.

12 Famà and Tusa (2000).

13 Grotta (2010), 231.

14 Horden and Purcell (2000); I. Morris (2005), 51; Malkin (2011); Bonnet (2014).

15 Niemeyer (2006), 157: "Phoenician expansion ... represented something dramatically different in purpose from Greek colonization, which focused mainly on the acquisition of arable land.”

16 Whittaker (1974); De Angelis (1994); Aubet (2001), 314-316; De Angelis (2003a), 120; Foxhall (2005).

17 Malkin (2011), 130. 
It has become a truism that the ancient Greeks constructed their ethnic identity in an agonistic fashion: they defined themselves by what they were not, and by their superiority to the "other," lesser cultures they encountered. ${ }^{18}$ Indeed, Malkin has argued that the Hellenic identity itself came into existence as a result of the Greeks' founding of new poleis in the Mediterranean. ${ }^{19}$ In the early Iron Age, when Greek and Phoenician exploration and settlement were taking place, it seems that cultural boundaries were more permeable than the later "classic" construction of Greek identity would allow. "Hybridization" in new settlements could lead to an entirely new culture. ${ }^{20}$ Trade and artistic influence did not flow in only one direction; therefore a "Hellenocentric narrative" is not the best explanation of these societies' culturally plural roots. ${ }^{21}$ The new "post-colonial” view emphasizes the cultural vacuum of the Sicilian "middle ground," in which natives, Greeks and Phoenicians interacted, competed and collaborated. ${ }^{22}$

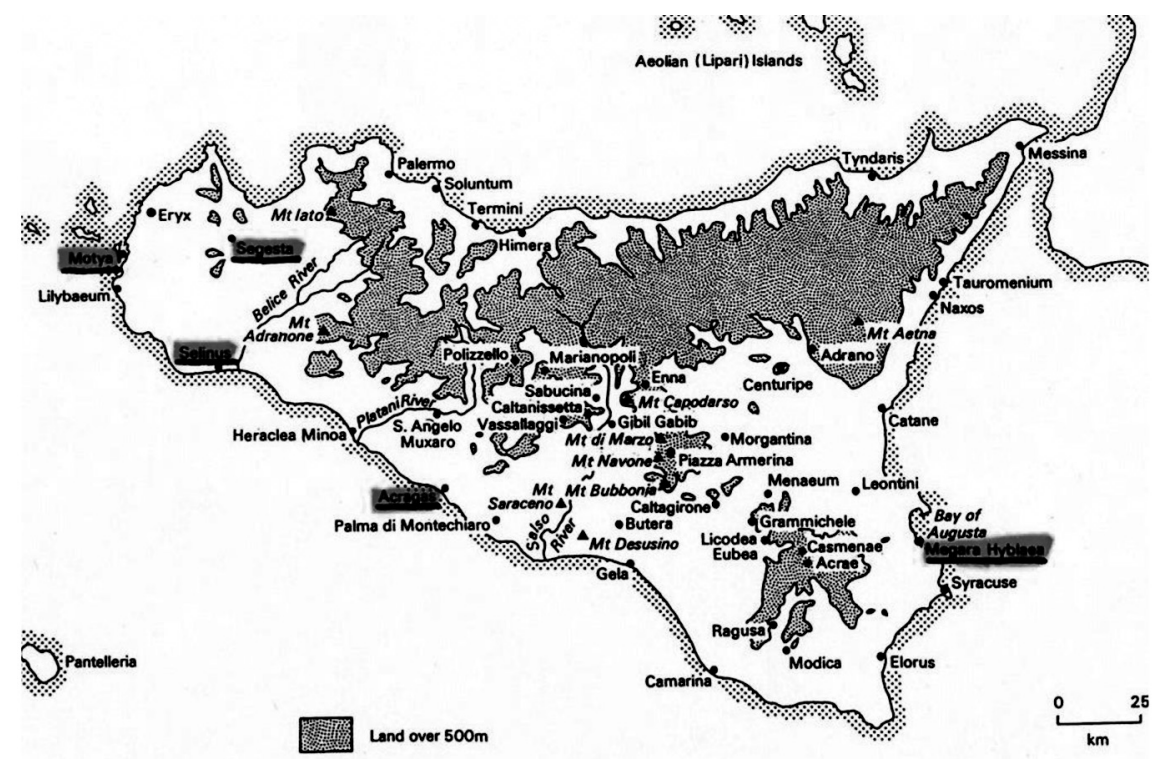

Fig. 2: Map of Sicily with major sites in green. After I. Morris (2001), 254.

18 Cartledge (2002).

19 Malkin (2013), 59: “... overseas colonization informed and strengthened the nascent idea of Greekness.” Also, Malkin (1987).

20 Hodos (2006), 16-17.

21 Schmitz (2001), 636.

22 De Angelis (2003b), 28. 
Selinus was the most westerly of the Greek foundations on the southern coast of Sicily, $75 \mathrm{~km}$ west of the nearest Greek city, Acragas (Fig. 2). It was something of a frontier town, confronting the established (eighth century BC) Phoenician city of Motya some $45 \mathrm{~km}$ to its northwest. Selinus was also about $35 \mathrm{~km}$ south of Segesta, capital of the Elymians (the indigenous population of northwestern Sicily). The complexity of Selinus' political and military alliances as well as its cultural development is a direct consequence of its geographical position amidst Greeks, Phoenicians and Elymians.

The history of Selinus begins in 728 BC with Megara's establishment of a colony on Sicily's east coast, Megara Hyblaea (Thuc. 6.4.1). Within eighty years of its founding, the city was already feeling the constraining influence of the powerful city of Syracuse and its allies to north and south. Unable to expand in its immediate vicinity, Megara Hyblaea planted a colony across the island, $215 \mathrm{~km}$ to the west. ${ }^{23}$ The founding of Selinus is dated to 651 by Diodorus (12.59.4), 628 by Thucydides (6.4.2). ${ }^{24}$ The settlement of Selinus was not the result of overpopulation at Megara Hyblaea, but rather a strategic move; the new colony had a vast swath of territory in which to expand, as well as a choice of new trading partners and political alliances. Megara Hyblaea, through its colony Selinus, was now linked to the nodes of the Phoenician-Elymian network in western Sicily. ${ }^{25}$

This location ensured a diverse population in the city. Although the earliest occupation level at Selinus shows evidence of indigenous elements, the Megarian settlers seem to have arrived peacefully among them. Etruscan and local indigenous pottery has been found on the acropolis of seventh century Selinus, which would seem to indicate the presence of non-Greeks at the city's founding. ${ }^{26}$ Inscriptions of the sixth and fifth centuries attest to the presence of Sicans, Phoenicians and Etruscans. ${ }^{27}$

In the sixth century Selinus was at the height of its wealth and influence. Although earlier attempts at expansion had been checked by Segesta and Motya (Diod. Sic. 5.9.2-3), an alliance with Carthage in the mid-sixth century enabled Selinus to expand its borders. ${ }^{28}$ However, the defeat of Carthaginian forces by Syracuse in 480 obliged Selinus to join the Greek alliance, where it stayed for most of the fifth century (Diod. Sic. 11.68.1-2). ${ }^{29}$

23 For a more detailed history: Fischer-Hansen, et al. (2004), 220-224.

24 Malkin (2011), 79, 192; Morakis (2011), 478.

25 De Angelis (1994); Marconi (2007), 63; Hornblower (2008), 10-12.

26 Marconi, et al. (2015), 330-331.

27 Robu (2011), 3; S. Morris (2019), 81-82.

28 De Angelis (2003a), 155-159.

29 De Angelis (2003a), 160-162. 
In 416, Selinus, with Syracusan support, defeated Segesta in a war over disputed territory (Thuc. 6.6.2; Diod. Sic. 12.82.3-4). Segesta appealed to Athens for help, and the city sent an armada to Sicily which was destroyed by the Syracusan alliance in 415 (Thuc. 6.67.2; Diod. Sic. 13.54.2). ${ }^{30}$ Selinus took advantage of this victory to seize Segestan territory. Segesta requested aid from Carthage, as did Selinus from Syracuse, and thus began the Carthaginian war, which ended in the Carthaginian conquest of Selinus in 409 (Diod. Sic. 13.54-62). The Selinuntine strategy of nimbly manipulating alliances was no longer effective in preserving her independence.

Carthage now controlled Selinus and, effectively, western Sicily (Diod. Sic. 1 3.114.1-2). Under Carthaginian occupation, the population became more mixed. Under Punic military occupation, the city's architecture became more syncretic, especially in a cultic context. ${ }^{31}$ During the fourth century, Selinus was a disarmed tributary ceded back and forth between Syracuse and Carthage. Finally in 268 or 250 BC, the city was razed and the population moved to Lilybaeum (Diod. Sic. 24.1; Strabo 6.2). The ruins remain unoccupied.

\section{Development of the sanctuary area}

Gabrici's excavations led him to conclude that Zeus Meilichios was subordinate to Demeter Malophoros, perhaps even her consort, as he believed that her larger sanctuary included his smaller precinct. More recently it has become clear that the precinct of Zeus Meilichios was outside the peribolos wall of the Demeter Malophoros sanctuary. ${ }^{32}$

I will discuss the sacred complex as made up of three parts: 1). the sanctuary of Demeter Malophoros, with its precinct of Hecate, temple of Demeter, propylon and dining rooms; 2). the precinct of Zeus Meilichios in the northeast corner of the site, which contains a naïskos and altars; and 3). the unwalled Field of Stelae west of the precinct. These three will be referred to here as the Malophoros sanctuary, the Meilichios precinct, and the Field of Stelae, outlined in green, in blue, and in red, respectively (Fig. 3).

30 Hornblower (2008), 301-303; Marconi, et al. (2015), 332.

31 De Simone (2010), 183; Marconi (2012), 22-23 and (2014).

32 Dewailly (1992), 36-37; Grotta (2010), 23-27. 


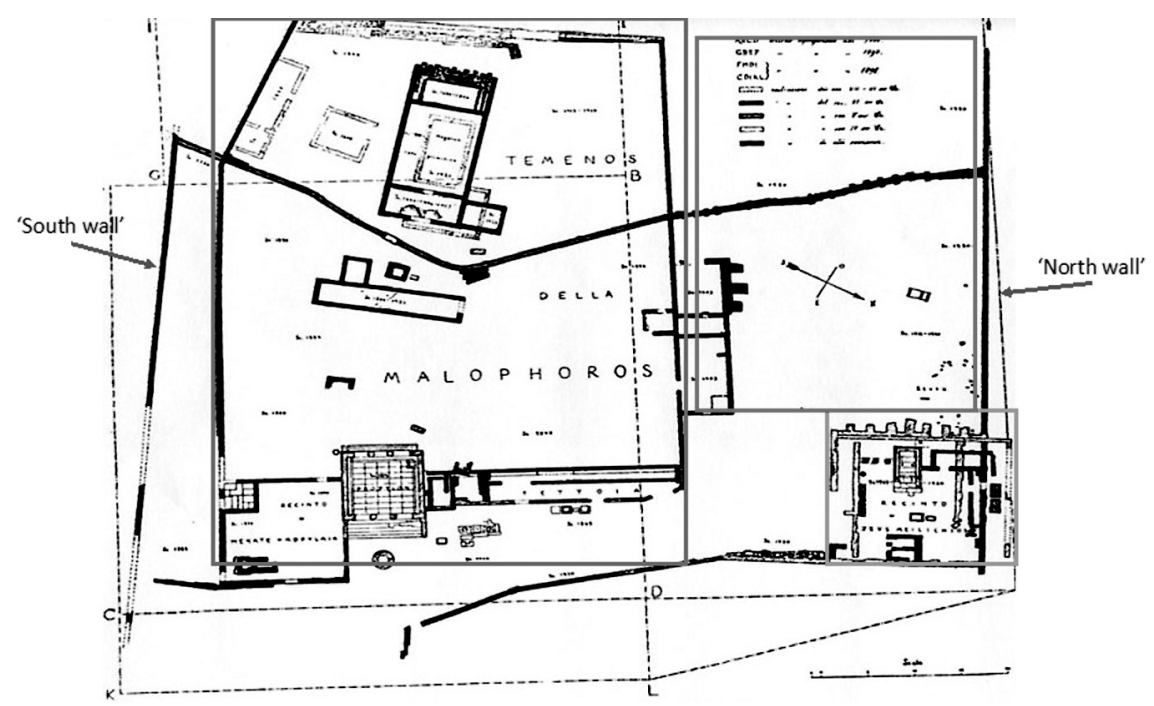

Fig. 3: Three divisions of the sanctuary area: green: Malophoros sanctuary; blue: Meilichios precinct; red: Field of Stelae. After Gabrici (1927), Pl. 2.

Excavations at the Malophoros sanctuary have revealed a late eighth-century pre-colonial stratum showing indigenous cultic activity before the Greek organization of the sanctuary. ${ }^{33}$ The discovery of five sherds of indigenous "Elymian" pottery at the lowest layer of the Malophoros sanctuary, in contact with imported seventh-century Greek pottery, led one excavator to hypothesize a period of "peaceful co-existence" between natives and immigrants at the time of Selinus' founding in the mid-seventh century. ${ }^{34}$ Late seventh-century Greek votive dedications have also been found in the northwest corner of the Field of Stelae. ${ }^{35}$

A late Archaic votive plaque from the Malophoros sanctuary has been identified as the oldest sculptural representation of the rape of Persephone (ca. 510 BC). ${ }^{36}$ This relief links Demeter Malophoros to the founding myth of the Eleusinian cult, the story of Persephone's rape, as told by the sixth-century Homeric Hymn to Demeter. Clearly Malophoros could not have been originally a generic "Mediterranean goddess" whose name only later became an epithet of Demeter. ${ }^{37}$

33 Dewailly (1992), 3-6; Famà and Tusa (2000), 81; Grotta (2010), 7-9.

34 S. Tusa (1982), 117. This indigenous "Elymian" pottery is now dated to the second half of the seventh century: personal communication with C. Marconi, February 6, 2019.

35 Dehl and Dewailly (1986), 65-66.

36 Marconi (2007), 175 and (2009), 202.

37 Riotto (1985), 46. 
Beginning in the sixth century, hundreds of sacrificial deposits, called "hearths" by Gabrici, were placed throughout the sanctuary area: in the Field of Stelae, in the Malophoros sanctuary and the Meilichios precinct. These deposits included burnt rodent and bird bones, ash, lamps, broken and burnt pottery, terracotta figurines, and metal offerings such as spear points. Many hearths had stelae set up above as a memorial of the sacrifice. ${ }^{38}$

At some time at the end of the sixth century, according to Dewailly, the Meilichios precinct was shifted to the west and elevated two meters by an earth embankment, perhaps to protect it from the flooding of the Modione river. On the new surface covering the earlier deposits, the naïskos and precinct wall were built in the early fifth century. ${ }^{39}$ The deposition of sacrifices and their associated stelae continued in the Meilichios precinct and the Field of Stelae through the fifth century and into the Punic period.

Two epigraphical finds from the Malophoros sanctuary identify the deity: a fragmentary dedication "to Malophoros" on a black figure olpe (sixth-fifth century), ${ }^{40}$ and a fifth-century dedication: "Theullos, son of Pyrrhios, dedicated [this] to Malophoros, for a vow on the sea."41

Finally, the goddess's importance is indicated by her inclusion in the wellknown fifth-century "Victory" inscription from Temple G, which gives thanks to the major gods of Selinus, "Zeus, Phobos, Herakles, Apollo, Poseidon, the Tyndarids, Athena, Malophoros, Pasikrateia and the other gods." ${ }^{42}$ It has been suggested that Demeter, as Malophoros, and Persephone, as Pasikrateia, shared the sanctuary on the Gaggera. ${ }^{43}$

In $420 \mathrm{BC}$ the Malophoros sanctuary was embellished by a propylon, a monumental entranceway into the sanctuary, intended to evoke Eleusinian parallels (Fig. 4). This propylon was square, an unparalleled arrangement in Greek architecture. Its shape and measurements have been interpreted as an expression of Pythagorean ratios and number lore. In short, the propylon represents a cosmo-

38 Gabrici (1927), 122, 156-157; Dewailly (1992), 3-16, 37-38.

39 Dewailly (1992), 36-38. Or in the first half of the third century BC: personal communication with C. Marconi, February 6, 2019. Marconi (2009), 281.

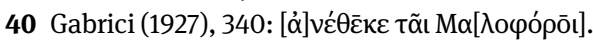



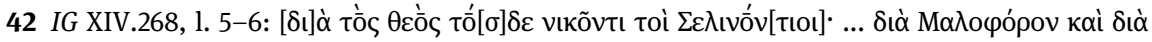



43 Dewailly (1992), 147-148; PGM IV.2770: the name Pasikrateia, “all-powerful," occurs in magical papyri; Usener (1948), 224.14: Pasikrateia is a personal name in three late funerary inscriptions; Graf and Johnston (2007), 151 n. 91: Pasikrateia is “the secret name of a powerful goddess”; Pasikrata had a sanctuary next to the Thesmophorion in Demetrias, Thessaly: Batziou-Eustathiou (2010), 194. 
politan style created under the influence of regional and Attic styles. The closest parallel to the propylon is the temple at Segesta, capital of the indigenous Elymian civilization. ${ }^{44}$



Fig. 4: Propylon of sanctuary of Demeter Malophoros. Photo by J. D. Mikalson.

After the Carthaginian conquest of Selinus in 409 BC, major changes took place in the architecture of the Malophoros temple and in the precinct of Meilichios. Sometime after 409, the rear pediment of the temple was removed and the roof was rebuilt with a barrel vault to support the weight of earth and sand which was now heaped up over the building to mimic the appearance of a chthonic underground shrine. According to White, these renovations made the buried rear adyton of the temple evocative of a Punic burial, and thus more suitable for the worship of chthonic deities.

The sanctuary of Demeter Malophoros now became sacred to Tanit and her paredros, Ba'al Hammon..$^{45}$ Tanit was the principal Punic goddess of the afterlife, who received infant holocaust sacrifices in the tophet. ${ }^{46}$ In the Punic world gen-

44 Miles (1998), 42-43, 57.

45 White (1967), 344-345, 351-352; Famà and Tusa (2000), 12 n. 8.

46 On this topic see Brown (1991), Stager (2011), Xella, et al. (2013). 
erally, Tanit and Ba'al were the chthonic pair in charge of fertility and the underworld. However, it should not go unremarked that there is no evidence of human sacrifice at Selinus, nor has any representation of Tanit been found on the Gaggera hill. ${ }^{47}$

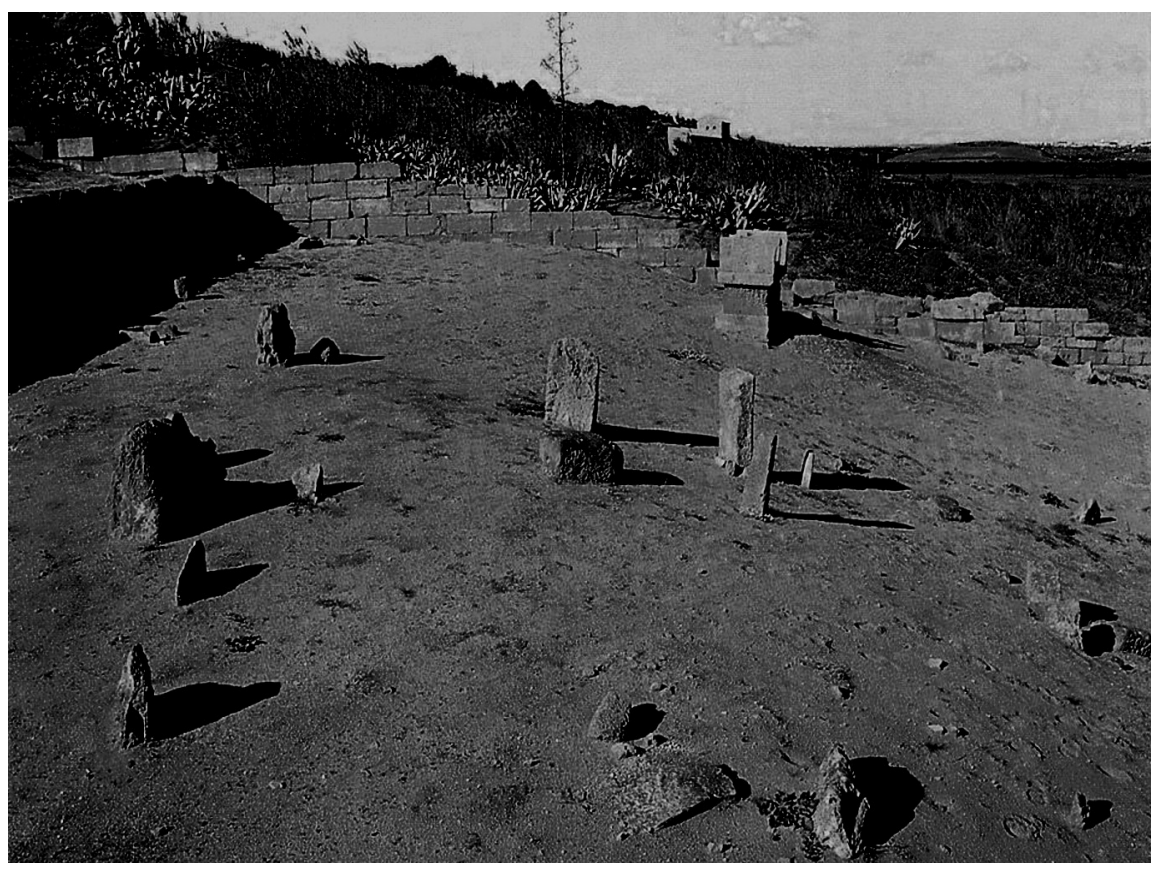

Fig. 5: "Campo di stele” from the south. After Famà and Tusa (2000), Pl. 3.1.

\section{The Field of Stelae}

Gabrici referred to the unwalled area west of the Zeus Meilichios precinct as a "campo di stele," or Field of Stelae, a term with connotations of the Punic tophet, even though the essentials - Punic inscriptions and cremated infant bones - are lacking. Nevertheless, the site's similarity in appearance to a tophet (Fig. 5) has encouraged the notion that the stelae are of Punic origin, even if influenced by

47 The "sign of Tanit" has been found on the Manuzza hill and the Acropolis of Selinus: V. Tusa (1971), 62 and (1976), 29-35; De Simone (2010), 184. 
Greek sculptural styles. ${ }^{48}$ Many of the stelae show signs of burning at their bases and were found with votive deposits consisting of burnt bones, pottery and figurines. ${ }^{49}$ Such stelae-crowned sacrificial deposits have been found at other Sicilian sites, and have been interpreted as a western Greek cultic practice, a means of marking a private, perhaps gentilicial, sacrifice, which included the communal meal of the kin group. Whether this practice evolved in the west under Punic influence or not remains to be seen..$^{50}$ White dates the naïskos after 409 , since its architectural style was particularly favored by Carthaginians rather than Greeks. However, Dewailly dates the naïskos to as much as fifty years earlier than the propylon of Demeter Malophoros. ${ }^{51}$

The god and goddess on the twin stelae have been compared to portrait types of Tanit and Ba'al from elsewhere in Sicily and north Africa. ${ }^{52}$ Although White identifies them as Tanit and Ba'al, he suggests that they were known as Persephone and Plouton to those Greeks still using the sanctuary in the fourth century. ${ }^{53}$ The two altars in front of the naïskos in the Meilichios precinct may also point to the worship of two deities.

\section{Interpretation of the archaeological evidence}

As noted above, many of the earliest excavators saw Selinus as a place of religious and cultural convergence, demonstrating not only the presence of native elements, Sicanians and Elymians, but also Phoenicians, who may have been resident in the city from the seventh century. Others have strongly protested that the evidence shows that Selinuntine culture, and especially the religious rituals on the Gaggera, were entirely Greek until 409 BC when the Carthaginian conquest led to a change in the deities worshipped as well as in the architectural elements of the sanctuary.

Demeter Malophoros. Although the deity of the larger sanctuary is named only as Malophoros, there can be little doubt that the reference is to Demeter Malo-

48 White (1967), 342-343.Gaifman (2012), 197-206 also sees the twin stelae as post-409 BC.

49 Gabrici (1927), 156-157; Dewailly (1992), 3-16; Famà and Tusa (2000), 28-31.

50 Bergquist (1992), 41-47; Jameson, et al. (1993), 102.

51 Dewailly (1992), 37.

52 Di Vita (1961-1964); see Famà and Tusa (2000), Pl. 17, no. 17.

53 White (1967), 349. 
phoros, whose cult is known from Megara and its colonies. ${ }^{54}$ It is logical to connect Demeter Malophoros at Selinus with her namesake at Megara, even though a sanctuary of Demeter Malophoros has not yet been found at Megara Hyblaea, mother city of Selinus.

Malophoros is closely associated with Megara, its colonies and associates. A third-century inscription from Anchialus on the Black Sea records a "thank-offer-

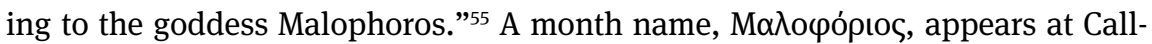
atis, a Megarian foundation (IScM III 38) also on the Black Sea. This month name suggests a Malophoria festival. ${ }^{56}$ A medieval citation of a calendar of Byzantium, also a Megarian colony, attests the same month, and notes that it coincides with September: Malaforus Byzantorum lingua september mensis dicitur. ${ }^{57}$

The meaning of the epithet Malophoros is disputed between "sheep-" or "fruit-bearer." ${ }^{8}$ Although Pausanias, in his visit to the shrine of Demeter Malophoros at Megara Nisaea, explains her title as "sheep-rearing" (1.44.3: $\pi \rho o ́ \beta \alpha \tau \alpha$... $\theta \rho \varepsilon ́(\alpha \nu \tau \alpha \varsigma)$, the first element of her title is more likely to derive from $\mu \tilde{\alpha} \lambda o v$, "treefruit," since Demeter has no pastoral connections..$^{59}$ Besides the epigraphical evidence, Perale cites five literary examples where the name Malophoros cannot possibly mean "bringer of flocks." 60

The Pomegranate. That Malophoros means "bringer of tree fruit" is beyond doubt, despite Mantzoulinou-Richards' ingenious arguments. But which tree fruit? One could argue that the fruit in question was not the apple or the quince or even the citrus, but the pomegranate. This fruit was not an everyday food, but an exotic item connoting wealth and luxury. As early as the third millennium in the Near East, the pomegranate was a luxury food, portrayed in precious materials and placed in tombs. Symbolically the pomegranate was associated with fertility and the afterlife. By the end of the Bronze Age, Greeks had learned to treasure this fruit and to associate it with high status and mythological significance. ${ }^{61}$

54 Cordano (2012).

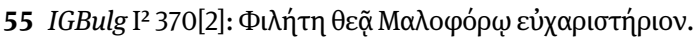

56 Trümpy (1997), 153.

57 Perale (2009), 229.

58 Mantzoulinou-Richards (1986), 15-22, but see Perale (2009).

59 Farnell (1907) 3.32; Jameson, et al. (1993), 133 n. 2; Perale (2009), 230.

60 Perale (2009), 236.

61 C. Ward (2003), 530. 


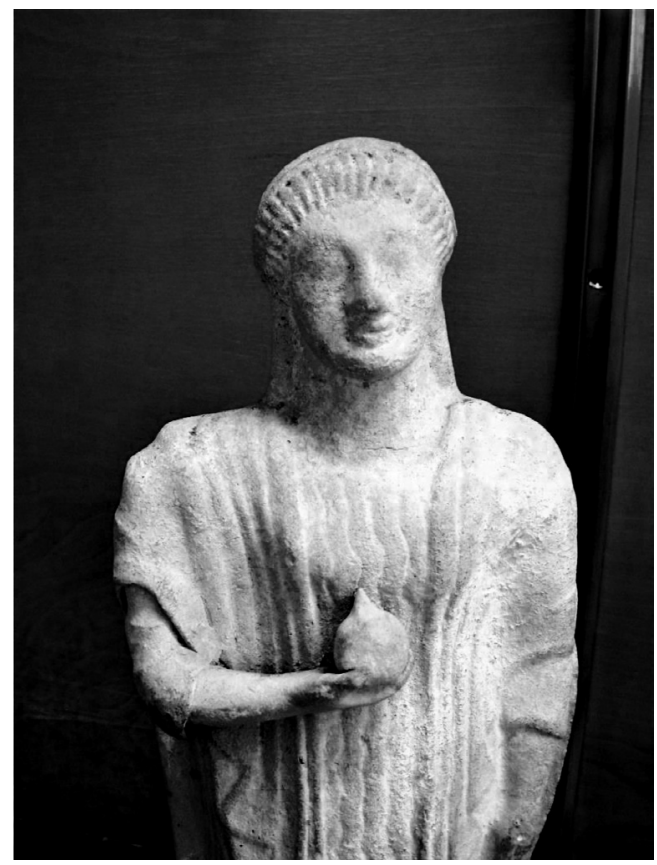

Fig. 6: Female terracotta votive with pomegranate, sixth century BC. Archivio Fotografico del Museo Archeologico Regionale Antonino Salinas di Palermo. Photo by author.

Votive figurines dedicated in the Malophoros sanctuary show the goddess holding the pomegranate (Fig. 6). The pomegranate was a vital element in the story of Persephone's rape and return: the reason, in fact, why she was obliged to spend one-third of her life as the Queen of the Underworld, since Hades "by

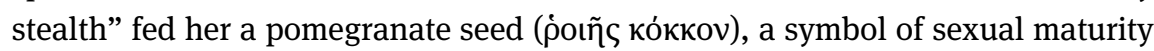
and marital consummation. ${ }^{62}$ After eating the pomegranate seed she could not return to her maiden status as the Kore. Henceforth, her seasonal ascent and descent mirrored the life and death of the grain (Hom. Hymn Dem. 390-400). Persephone's cult in Sicily and Southern Italy stressed her role as Queen of the Underworld, $\chi \theta o v i \omega v \beta \alpha \sigma i \lambda \varepsilon \alpha^{6} .{ }^{63}$ South Italian pinakes show her as Hades' enthroned Queen, holding the pomegranate. ${ }^{64}$

62 Hom. Hymn Dem. 410-412. The pomegranate also symbolized the sexuality of Hera and Aphrodite: Faraone (1990).

63 Graf and Johnston (2007), 12-19.

64 Sourvinou-Inwood (1978), 103-111. 
Tanit and Demeter. The pomegranate was also an attribute of the Phoenician fertility goddess Astarte, and of her hypostasis, the Punic goddess Tanit, who enabled Ba'al, the spirit of the vegetation, to be reborn from the earth. Tanit was identified with Kore but she was also a kourotrophos; the Romans called her the nurse of Saturn (Ba'al). ${ }^{65}$ As the principal Punic underworld deity, Tanit appears in tombs as well as in the tophet. Hundreds of votive urns containing mlk sacrifices, holocausts of young children or animal substitutes, were deposited in the tophets of Carthage, Sardinia, Sicily, and North Africa. ${ }^{66}$ The mlk sacrifice was believed to regenerate the forces of fertility; the sacrificed male infant, apparently identified with the deity, was described as becoming a hero after death. This regeneration of the sacrificial hero may ultimately derive from an important annual ceremony known from Phoenician Tyre, called the "awakening," in which the god Melqart's ritual cremation on a pyre was followed by his resurrection. ${ }^{67}$

Tanit was a chthonic deity, connected with reproductive fertility and the netherworld, just as Demeter, goddess of the grain, had underworld associations through her daughter Persephone. Demeter was connected with Tanit's cult in the western Mediterranean even before the worship of Demeter and Kore was officially introduced into Carthage in 396 BC (Diod. Sic. 14.77.4-5). In Sicily and Sardinia, the goddesses can be found together at rural cult sites. ${ }^{68}$ An example of the blend of Demeter and Tanit iconography is a second-century BC funerary monument from Lilybaeum, decorated with the sign of Tanit, the caduceus and pomegranates; the grain basket (kalathos) of Demeter is above. The Greek inscription names the deceased, Diodoros, who is shown feasting within (Fig. 7). ${ }^{69}$

65 Lipinski (1995), 204-206.

66 Brown (1991), 29-33.

67 Dussaud (1946), 207; Aubet (2001), 153-154.

68 White (1967), 346-348; Van Dommelen and López-Bertran (2013), 283-284.

69 Bisi (1967), Pl. 14; Moscati (1973), 169; Brown (1991), 142, Figs. 58c-d. 


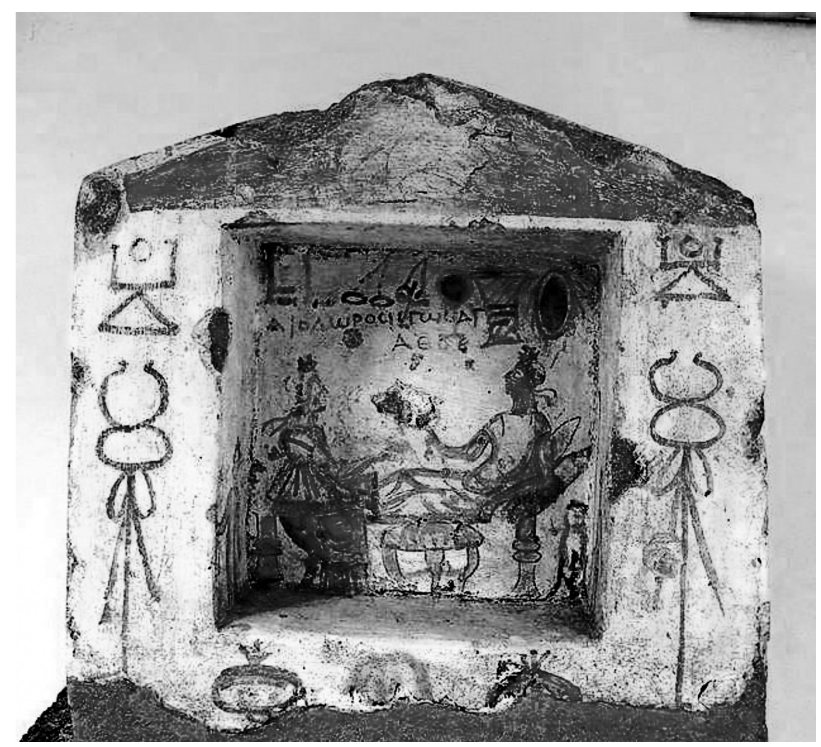

Fig. 7: Funerary aedicula of Diodorus, second century BC. Archivio Fotografico del Museo Archeologico Regionale Antonino Salinas di Palermo. Photo by author.

Zeus Meilichios. This chthonian Zeus is well known from Greece. Zeus Meilichios, "the appeasable," sometimes simply $\mu \varepsilon ı \lambda i x ı \varsigma, \mu ı \lambda i x ı$ o or plural, $\mu \varepsilon i \lambda i x ı$, had a purificatory function; he averted vengeful spirits and cleansed from the miasma of pollution. As a god of purity and of families, he ensured the prosperity of the family and the purity of its hearth. A holocaust sacrifice to Zeus Meilichios could ensure the prosperity of an individual (Xen. Anab. 7.8.4-5). Zeus Meilichios could also cleanse the city from the pollution of civic strife: in the lex sacra from Selinus, he is invoked in purification rites which repel unwanted spirits. ${ }^{70}$

Zeus Meilichios can appear as a bearded snake (Fig. 8), a creature with chthonic associations. ${ }^{71}$ This is not Olympian Zeus, wielder of the thunderbolt and guarantor of justice, but a humble family god; he is the resident household snake who receives daily offerings in return for his protection of the family storeroom and household wealth. ${ }^{72}$ Zeus Meilichios is also shown on dedicatory reliefs as a bearded deity accompanied by a snake, receiving a family group which ap-

70 IGASMG I² 53bis. Jameson, et al. (1993), 5-7, 50-55 suggest that the inscribed lead tablet may have been found on the Gaggera, and that the twin stelae may have played a role in the ceremonies. 71 Gourmelen (2012), 323-343.

72 Nilsson (1961), 65-72; Zeus Ktesios was also a snake. 
proaches leading a sacrificial animal. Like other guardians of the agricultural wealth which issues from beneath the earth, he has underworld associations. Zeus Meilichios is clearly an ancestral family god who protects the household, its members and its wealth, and is especially called upon to ward off the pollution of bloodshed..$^{73}$

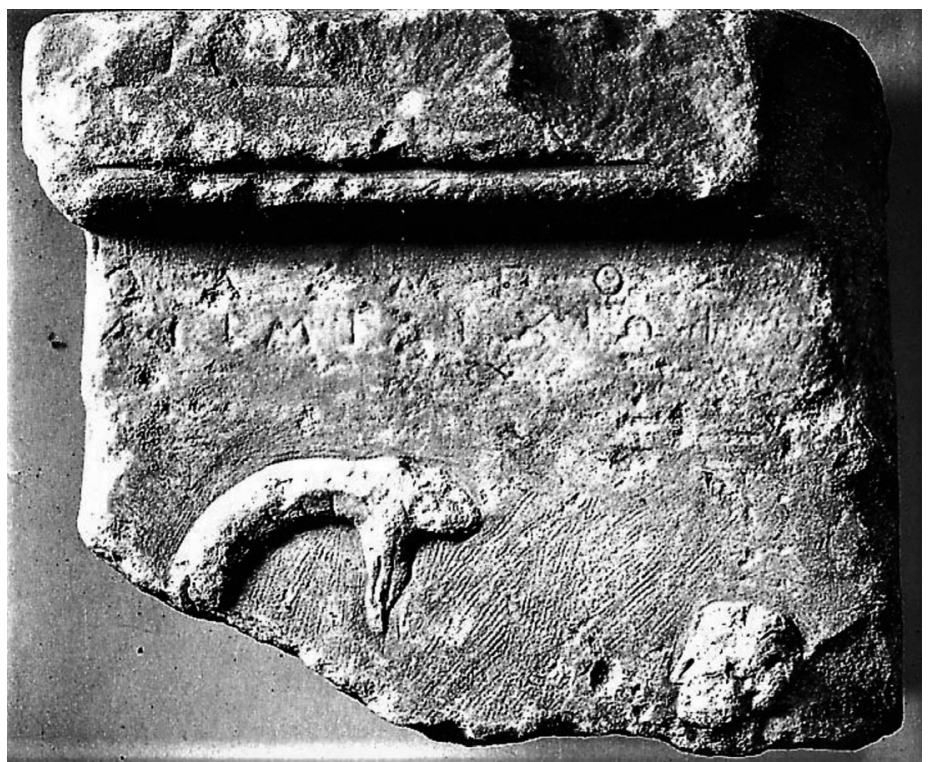

Fig. 8: Zeus Meilichios as a snake, fourth century BC. American School of Classical Studies at Athens: Agora Excavations (\#I 2201). Photo by author.

Zeus Meilichios' Athenian festival was the Diasia, "the greatest festival of Zeus." " It was celebrated outside the city at Agrai, an extramural sanctuary similar to the Meilichios precinct on the Gaggera. The Diasia was not a polis festival but was celebrated by each family with its own private sacrifice. Here there was no priest of Zeus Meilichios to officiate; the people offered their sacrifices individually (Thuc. 1.126.6; Hsch. s.v. $\Delta \dot{\alpha} \sigma i \alpha)$. This avoidance of commensality at the Diasia is reminiscent of the Choes of the Anthesteria, another ill-omened feast day with a similar focus on pollution and family. ${ }^{75}$ It seems that the Diasia was not

73 Jameson (1965), 159-162; Parker (2005), 41-42.

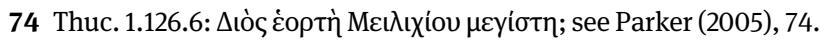

75 Burkert (1985), 238. 
celebrated in the demes, but that deme officials took sacrifices to Agrai. ${ }^{76}$ Despite its underworld connotations, this festival had a family atmosphere, where feasting and gifts for children played a role (Ar. Nub. 408, 864). Shrines of Zeus Meilichios were scattered in different quarters of Athens. This reflects the local, popular nature of the cult, which did not celebrate a poliadic deity, but a local or family god representing the ancestral dead. ${ }^{77}$ His cult was not limited to Attica or mainland Greece but is attested also in the Aegean islands, Crete, Asia Minor, the Black Sea, Cyprus, Cyrene, Italy and Sicily. ${ }^{78}$

According to Jameson, et al., Zeus Meilichios was worshipped on the Gaggera hill in a gentilicial cult which required repeated rituals, often involving a sacrifice, a communal meal, and even the erection of a new stone. The formulaic Greek dedicatory inscriptions on the stones, dated to the sixth and fifth centuries, give the evidence for this cult: "I am (or I belong to) the (Zeus) Meilichios ..." and "the Meilichios of the patria of the daughters of Hermias and the daughters of Eukles."79 The Meilichios stone represents the ancestor of the patria, who requires periodic propitiation and remembrance. He is a symbol of the continuity and strength of the family. Jameson, et al. suggest that, at Selinus, his ceremonies did not take place in a family plot, but, as in the Diasia sanctuary at Agrai, the Meilichios precinct in Selinus is available to each family to perform its own private rite when appropriate. ${ }^{80}$ Patriai and gene, gentilicial groups made up of the descendants of a founding figure, played an important role in the colonies founded by Megara in the Black Sea area such as Byzantion and Callatis as well as in Selinus. They were a means for the original allotment of kleroi at the founding of the colony, and they also preserved the ancestral traditions of the Megarian homeland..$^{81}$

The name Meilichios. Meilichios, meaning "he who can be appeased," is derived from $\mu \varepsilon \imath \lambda i \sigma \sigma \omega$, "to soothe, propitiate" (particularly the dead: Hom. Il. 7.410; or chthonian Demeter: Hom Hymn Dem. 290). Popular etymologies derive the name from $\mu \varepsilon^{\prime} \lambda$ ı (honey) or from $\mu \varepsilon^{\prime} \lambda \iota \alpha$ (figs). Meilichios is therefore the "sweet god."

76 The residents of Erchia took their sacrifice to Agrai (LSCG 18, A 37-43); Thorikos may have done likewise (SEG 33:147, 33-35).

77 Parker (1996), 240-242; Lalonde (2006), 69.

78 Jameson, et al. (1993), 81-91.

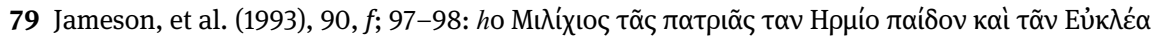
$\pi \alpha i \delta<0>v$; Robu (2009), 277-278, sees the patria as a fictitious kin group, descendants of a heroized founder.

80 Jameson, et al.(1993), 93-94.

81 Robu (2009), 288. 
Another etymology, first proposed over one hundred years ago, derives the epithet Meilichios from Molek or Moloch, the Canaanite-Phoenician deity of infant holocausts mentioned in the Hebrew Bible. ${ }^{82}$ It has been argued that this Semitic deity became known to the Greeks through contact with Phoenician traders, was imported into the Piraeus and somehow became identified with Zeus Meilichios. ${ }^{83}$ Quite aside from the dissimilarity between the appeasable and family-oriented Zeus Meilichios and the child-devouring Molek, this etymology loses credibility from recent studies which show that there was no such deity as "Molek."

According to the Hebrew Bible, sacrificing children to Molek in the fire of the Jerusalem tophet was punishable by death. ${ }^{84}$ It now appears, however, that Molek, the supposed Semitic deity of infant holocausts, is a phantasm born of later rabbinical commentary. Recent etymological and archaeological work shows that $m l k$ is not the name of a god, but a type of sacrifice. The Punic mlk sacrifice was the offering of a newborn male child, whose cremated bones were buried in an urn beneath a stela dedicated to Ba'al and/or Tanit. ${ }^{85} \mathrm{Mlk}$ is not a divine name, but refers to this holocaust ritual. ${ }^{86}$ In Hebrew literature as in Punic inscriptions, the word $m l k$ (molek or mulk) signifies a sacrifice rather than a divine name. ${ }^{87}$

The use of the epithet Meilichios "gentle, appeasable" for a deity with a rather frightening chthonic aspect is in the venerable Greek tradition of giving a euphemistic name to an underworld power. To call a god's name might summon him;

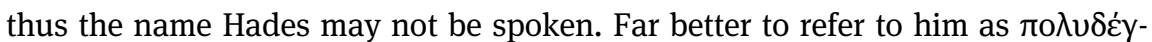

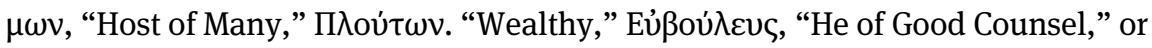

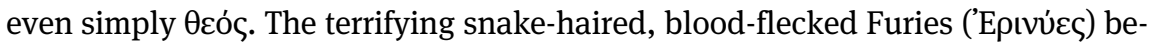
come the more approachable "Reverend Ones" ( $\Sigma \varepsilon \mu \nu \alpha i)$ or "Kindly Ones" (Eủ $\mu \varepsilon$ -

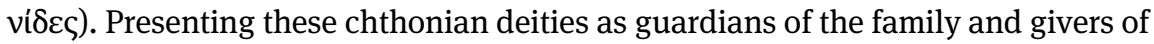
fertility and wealth makes it possible to approach them with less trepidation. Thus

82 Foucart (1904), 1700; Heider (1985); Day (1989); Dewailly (1992), 149; Jameson, et al. (1993), 140-141; S. Morris (2019), 72-74.

83 Zeus Meilichios also had a shrine in the Piraeus: Parker (1996), 241.

84 Lev. 18:21; Lev. 20:2; I Kings 11:7; II Kings 23:10; Jer. 32:35.

85 Stager (1980); Stager and Wolff (1984); Reynolds (2007); Stager, et al. (2011); Cross (2012); Xella, et al. (2013).

86 Brown (1991), 29-33 explains the three kinds of mulk sacrifice: of a noble male child (mulk ba'al), a male child (mulk adam), and an animal substitute for a child (mulk 'immor). Punic apologists who argue that the Tophet was a cemetery for still-born or young children must explain the dedicatory inscriptions over the cremation urns, typically " $\mathrm{X}$ dedicated this mulk ba'al to Ba'al Hammon because he heard the sound of his words."

87 Reynolds (2007), 150. 
Hades and Persephone are depicted in art with symbols of agricultural fertility, rather than as the ominous rulers over the dead. ${ }^{88}$

Curse Tablets. Twelve lead curse tablets, dated to the fifth century, have been recovered from the Meilichios precinct. Curse tablets were usually deposited in graves and in the sanctuaries of chthonic deities; they would certainly have been at home in the Malophoros sanctuary or the Meilichios precinct. ${ }^{89}$ The curse tablet, by simply naming the cursed person, or indicating his fate ("may his tongue be twisted") works by the miasma of the dead man with whom it is associated to carry out the curse. The hostile spirits of the dead, especially those whose funerary rites have been neglected, are easily mobilized to carry out the writer's curse. Such hostile spirits must have been numerous at Selinus, judging from the large number of curse tablets found there. ${ }^{90}$ Late sixth- and fifth-century defixiones inflict curses upon Greek, Phoenician and Sikan names, as well as many names based on the Greek xenos (stranger). It seems that intermarriage took place between Greeks, Phoenicians and Sicilians, a possibility already suggested by Thucydides (6.6.2)..$^{91}$

Altars. The only structure essential to a sanctuary is an altar, and their number or style is often read as an indication of the nature of the deity or deities worshiped within the temenos. The Malophoros sanctuary displays a large altar before the temple and a smaller one in the precinct of Hecate, indicating the presence of these two goddesses. Similarly, the two differently sized altars before the naïskos in the Meilichios precinct are taken as evidence that cult was offered here to two deities, Zeus Meilichios and his un-named consort. Two other altars have been found in the Field of Stelae, whose Punic associations have made them controversial.

88 Hom. Od. 2.29; pinakes from Locri Epizephyrii: Jameson, et al. (1993), 79; Burton (2011), 1-7. Clinton (1992), 61-62 and (1996), 166-169 distinguishes agrarian from chthonic deities.

89 Arena (1989); Jameson, et al. (1993), 125-131. Grotta (2010), 207 argues that the curse tablets are unrelated to Zeus Meilichios, but were all displaced from the Malophoros sanctuary by wind-blown sand and water.

90 The 22 curse tablets from Selinus represent more than half of all known Sicilian examples: Jameson, et al. (1993), 126.

91 Famà and Tusa (2000), 83; Collin-Bouffier (2010), 107-112; S. Morris (2019), 81-82. 


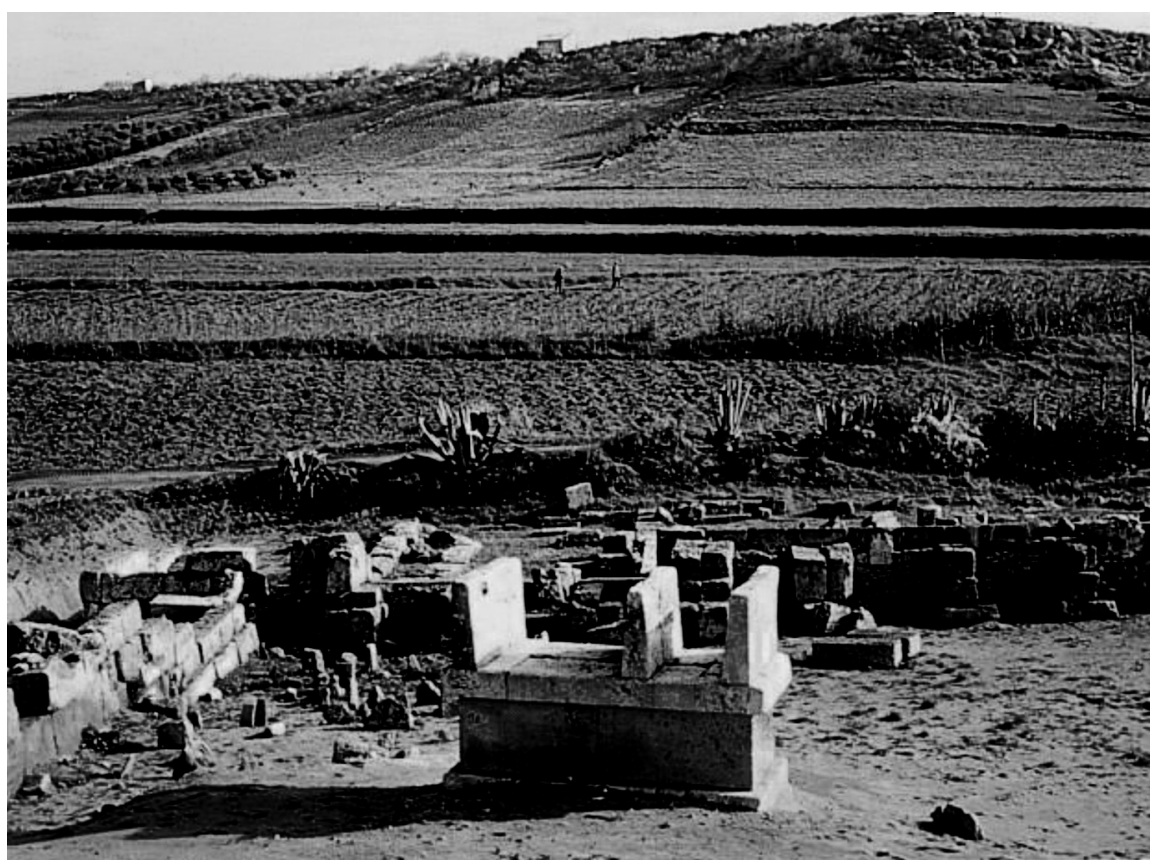

Fig. 9: Altar "with three baetyls" in the Field of Stelae, seventh century BC. After Famà and Tusa (2000), Pl. 3.2.



Fig. 10: Drawing of three-baetyl altar from Hadrumetum (Sousse), fifth century BC. After Cintas (1947), 66, Fig. 127.6.

The altar with three baetyls. An altar with three upright slabs set on its top can be seen today dominating the slope west of the naïskos (Fig.9). ${ }^{92}$ This unusual

92 Gabrici (1927), 104-105, Fig. 62. 


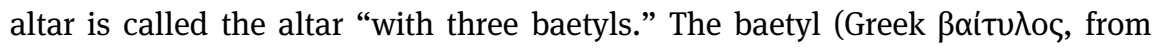
Semitic Bet $E l$ ) is a standing stone or aniconic object of worship known primarily from the ancient Near East. Such aniconic stones were also venerated in the Greek world as the dwelling of a deity or daemon..$^{93}$ Excavations in the last century completely cleared the sand and earth away from the base of the altar, down to "archaeologically sterile virgin soil," which would seem to confirm its use at a very early date. ${ }^{94}$ Associated pottery dates the altar to the sixth or fifth century, ${ }^{95}$ a date doubted by Grotta, on grounds of improbability: a Punic monument could not have appeared so early in a sanctuary which was, he argues, purely Greek. ${ }^{96}$

The earliest Phoenician monuments to divinity were such standing stones, which in the west evolved into the three baetyl form. On a fifth-century three baetyl altar from the tophet of Hadrumetum, the center stone represents the enthroned deity with protective animals on either side. Two other altars display three pillars or baetyls; urns beneath contained human and sheep bones (Fig. 10). ${ }^{97}$ Such an altar is depicted on the sixth century "stela of Hanno" from Lilybaeum. The altar with three baetyls is at the top; the caduceus is on the left, the "sign of Tanit' in the center next to an incense burner; the priest approaches from the right. The dedication, by Hanno, son of Adonbaal, to Ba'al Hammon, is inscribed below (Fig. 11). The three baetyl altar from the Field of Stelae is surely a Punic form, as nothing of this type is known from Greece; parallels to it have been found in Sicily, north Africa, the Levant, Sardinia and Phoenician Crete. ${ }^{98}$

93 Jameson, et al. (1993), 100-101.

94 V. Tusa, et al. (1984), 13.

95 V. Tusa (1971), 57; V. Tusa, et al. (1984), 13-15; Dewailly (1992), 37-38; Spagnoli (2003), 172 173.

96 Grotta (2010), 44; but see De Simone (2010), 186.

97 Cintas (1947), 65-66, Figs. 112-115.

98 Famà (1980) ; Shaw (1989), 169, Fig. 5; Brown (1991), 60; Spagnoli (2003) and (2005),141-145; Chiarenza-Roma (2007); De Simone (2010), 186. 


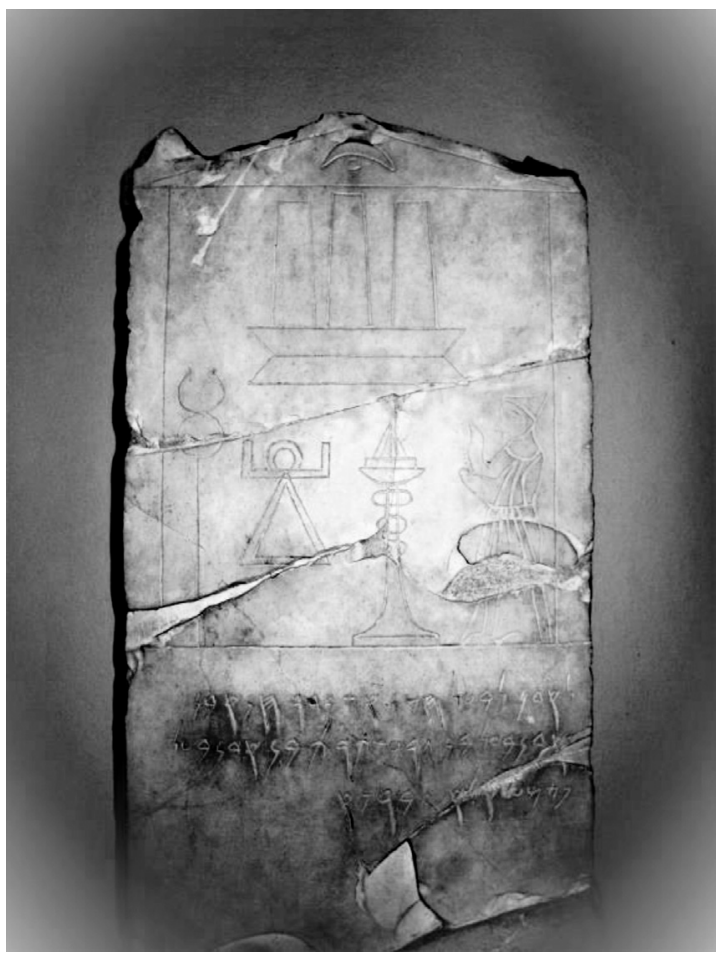

Fig. 11: Votive stela dedicated to Baal Hammon by Hanno, son of Adonbaal, from Marsala (\# 11258), sixth century BC. Archivio Fotografico del Museo Archeologico Regionale Antonino Salinas di Palermo. Photo by author.

The miniature altar. A miniature Punic altar inscribed מלך ים from the Meilichios precinct was part of the unprovenanced collection of objects, including the Lex Sacra and a few stelae, once in the Getty Museum in Malibu (Fig. 12). This inscription has been read as a theophoric personal name, b'd mlk, "servant of Molek." However, McCarter suggests the reading: “... 'bdmlk, a personal name ... This is a very common name type, and this specific name is widely attested in both Phoenician and Punic. The meaning of the name is 'Servant of Milk,' with milk, which means 'king,' referring to a god who is thought of as a divine king." "99 "The name should be translated as "servant of the Lord (Melqart or Ba'al)," not "servant of Molek." The proposed etymology for the name Meilichios as an Iron Age syncretism of the cult of the Semitic Molek and the Greek Zeus is thus unlikely. ${ }^{100}$

99 Personal communication with P. K. McCarter, November 19, 2015.

100 Jameson, et al. (1993), 139-140. 


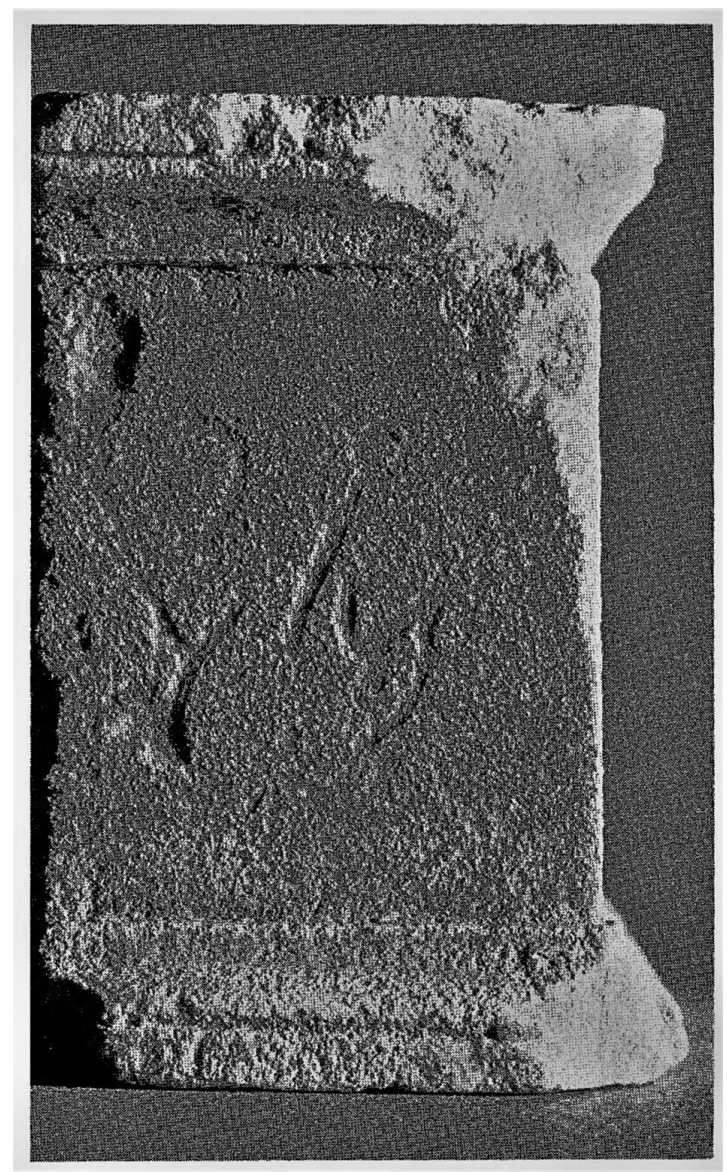

Fig. 12: Miniature limestone altar with Punic inscription (\# 81.AA.143), third century BC (H: $5.2 \times$ W: $6.2 \mathrm{~cm}$ ). Photo from the J. Paul Getty Museum, Villa Collection, Malibu, California, Gift of Dr. Max Gerchik.

The diminutive size of the altar suggests its private use. According to Spagnoli, this altar is a familiar article of Punic domestic cult and can be dated to the Roman period (third-first century BC). It is "similar, in shape and dimensions, to those found as votives in Punic sanctuaries and in domestic cult ... in Sicily, but also in Punic North Africa. Small altars or arulae were used in domestic cult for burning grain or incense." ${ }^{101}$ Therefore, this altar could be evidence of Punic household cult from the Carthaginian period of Selinus' history.

101 Personal communication F. Spagnoli, November 16, 2015. See Spagnoli (2015), 227, Fig. 26. 
The Twin Stelae. Finally, let us discuss the mysterious Selinuntine stelae with two heads, the chief object of this study, about whose identification and date there is so much doubt and controversy. Combining the Punic form of the aniconic stela with the Greek form of the sculptured head or bust, the twin stelae have no parallels in either culture. Consequently, their interpreters have assumed that they represent a syncretism of Greek and Punic traditions.

In Greek iconographic tradition, pairs or groups of goddesses are often depicted as joined at the hip with identical attributes. Double representations are especially common in the cults of Demeter and Kore or of Artemis and Hecate. However, these goddesses appear as sculpted busts or statuettes, not simply heads on a stela. ${ }^{102}$ The inscribed stela, on the other hand, in the shape of an obelisk or a flat panel, was the characteristic dedication of Phoenician-Punic cult. ${ }^{103}$ The paired divinities of Punic religion, usually a heterosexual pair, although similar to the twin stelae in concept, were not necessarily depicted together in stone. ${ }^{104}$

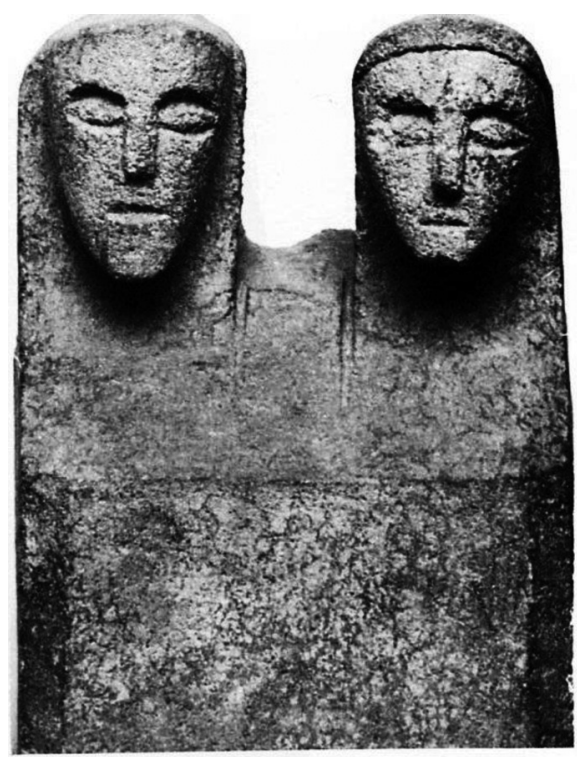

Fig. 13: Twin stela in Greek and Punic Style (\#5686), 600 BC. After Gabrici (1927), Pl. 28.3, Famà and Tusa (2000), Pl. 27, 58. Archivio Fotografico del Museo Archeologico Regionale Antonino Salinas di Palermo.

102 Hadzisteliou-Price (1971), 48-69, esp. Pls. 5-8.

103 Lipinski (1995), 212.

104 Xella (1990). 


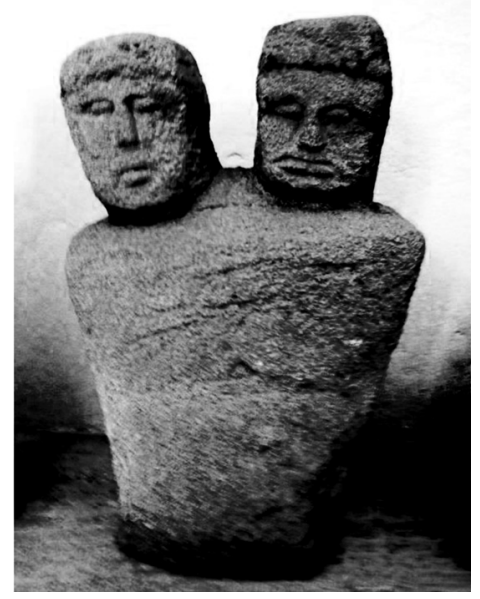

Fig. 14: Twin stela in Greek-indigenous style (\#5678), fifth century BC. Gabrici (1927), Pl. 29.8. Famà and Tusa (2000), Pl. 25, 52. Archivio Fotografico del Museo Archeologico Regionale Antonino Salinas di Palermo. Photo by author.

Over the twelve years of his excavations on the Gaggera hill, Gabrici found more than 100 crudely worked stelae. ${ }^{105}$ The stelae, many of which had two heads, one masculine and one feminine, were found in both the Field of Stelae and the Meilichios precinct, with deposits of burnt animal bones and pottery fragments at their bases, in layers of sand and ashes as much as two meters below the present ground level. He could not establish a clear stratigraphy for the stelae, since each deposition of a stela erased or confused the stratification of earlier ones. ${ }^{106}$ Therefore, Gabrici dated the stelae by style, as did Famà. ${ }^{107}$

On the other hand, the stylistically similar (although not two-headed) stelae found by the "Missione Malophoros" of 1969-1970 were dated by accompanying pottery. In that more recent excavation on the Gaggera, a number of sacrificial deposits topped by uninscribed, roughly shaped stelae were found in the northwestern angle of the Field of Stelae, upslope from the Meilichios precinct. These deposits are filled with ashes, burnt rodent and bird bones, Corinthian pottery, votive deposits and miniature terracotta agricultural tools, much like Gabrici's hearths found elsewhere in the sanctuary area. The deposits begin during the earliest use of the sanctuary area in the seventh century, are plentiful in the sixth and

105 Gabrici (1927), 175.

106 Gabrici (1927), 155-157.

107 Famà and Tusa (2000), 11, 17-19. These dates are doubted by the present excavator of Selinus, C. Marconi: personal communication, February 6, 2019. 
less so in the fifth; even though none of the stelae have two heads, they are similar in style and fabric to the twin stelae. ${ }^{108}$

The stelae in Famà's catalog number eighty-three; of these, I count sixty-four stelae topped by two heads, male and female. ${ }^{109}$ This list does not include the three twin stelae from the Getty museum, now returned to Selinus. ${ }^{110}$ All were made from Selinuntine sandstone, by local sculptors, not by skilled masons in a dedicated workshop. ${ }^{111}$ They show a great variety of styles: some are rough and crude, some show the influence of Greek style, and some are very simple and stark, although not unskillfully made (Fig. 13-16). The homemade quality of the stelae contrasts with more sophisticated ceramic finds from the sanctuary area, such as the protomes, the mold-made terracotta figurines, and the imported Corinthian pottery. ${ }^{112}$ Even though skilled artisans were available in Selinus, the twin stelae were carved by ordinary individuals, perhaps because they were for use in family cult.

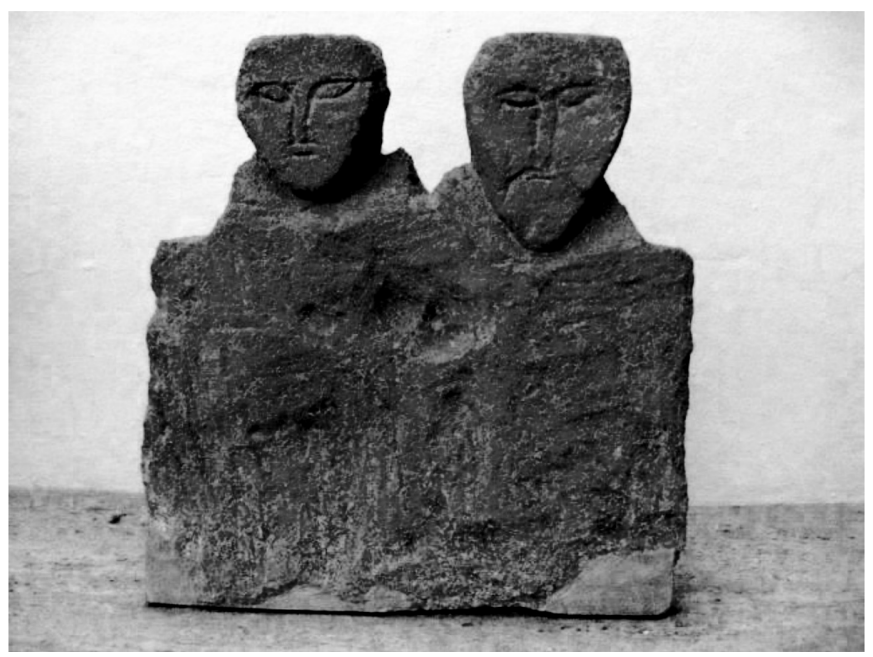

Fig. 15: Twin stela in Punic style (\#5666), after 409 BC. Gabrici (1927), PI. 29.2 Famà and Tusa (2000), Pl. 26, 55. Archivio Fotografico del Museo Archeologico Regionale Antonino Salinas di Palermo. Photo by author.

108 V. Tusa (1971), 56; V. Tusa, et al. (1984), 14 and n. 4; S. Tusa, et al. (1986), 66, Fig. 13.

109 Famà and Tusa (2000), Pl. 13-36.

110 Jameson, et al. (1993), p. 105-107, Pls. 12, 13 and 14.c-f and compare Pl.14.c-f to Famà and Tusa (2000), Pl. 27.57-58.

111 Famà and Tusa (2000), 32, 86, 88. On the significance of the amateur sculptors, despite the availability of professionals, see Wiener (2011), 10 .

112 Dewailly (1992), 134. 


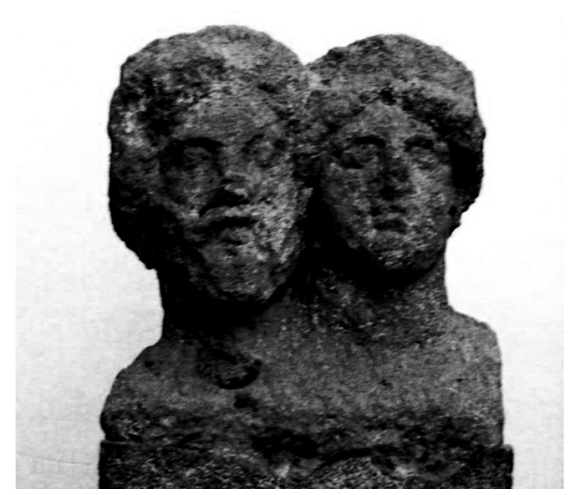

Fig. 16: Twin stela in Greek style (\#5685), after 300 BC. Gabrici (1927), Pl. 27.4, Famà and Tusa (2000), Pl. 33, 74. Archivio Fotografico del Museo Archeologico Regionale Antonino Salinas di Palermo. Photo by author.

Famà distinguishes three artistic styles, Greek, Punic and indigenous. The Greek style is most frequent in the sixth and fifth centuries, as the Punic is in the fourth, but the indigenous style, now Hellenized, now Punicised, appears throughout the life of the sanctuary. The crude indigenous stelae show elements comparable to Sikel and Elymian productions. ${ }^{113}$ The stelae show the influence of all three cultures, although Greek sculptors, as the pioneers of figural art in the Mediterranean, are the most obvious influence. This mixture of styles prevails from the end of the seventh century until well after the Carthaginian capture of the city in $409 \mathrm{BC}$, and perhaps into the third century. The stelae do not show a linear development; they do not become cruder or more finished over time. Their appearance seems to depend on the sculptors' abilities, the quality of the stone, and the effects of water and sand. ${ }^{114}$

Even though there is strong Punic influence in the representation of the divine couple, these carved effigies are a far cry from the typical depiction of the Punic deities. ${ }^{115}$ Normally these gods are represented as abstractions, engraved on stelae; the goddess Tanit manifested as the "sign of Tanit," and Ba'al as the caduceus. Elsewhere in the western Mediterranean, Semitic aniconic traditions remained strong, reinforced by north African models. ${ }^{116}$

113 Famà's “indigenous” category: Famà and Tusa (2000), 84-88.

114 Famà and Tusa (2000), 19, 26.

115 The Gaggera hill appears to have been a particularly Phoenician-Punic cult space: Spagnoli (2003); Chiarenza-Roma (2007); De Simone (2010), 186-187; S. Morris (2019), 70.

116 Brown (1991), 124-127 
Grotta's theory. Grotta's survey of the evidence provides a new interpretation of the Field of Stelae, a term to which he objects. ${ }^{117}$ He sees it as an exclusively Greek cult space for the Archaic-Classical cult of Zeus Meilichios. The only evidence he accepts for this cult is the fifteen inscribed "Meilichios stones," dated by their lettering to the sixth and fifth centuries. ${ }^{118}$ After the Punic conquest in $409 \mathrm{BC}$, this cult ceased to exist; the level of the earth was raised, the precinct was laid out and the naïskos and other structures were built. ${ }^{119}$

According to Grotta, whatever the uninscribed twin stelae are, they are not Greek, and are unrelated to the cults of Malophoros or Meilichios. The deities portrayed on the stelae are a mystery requiring investigation. His insistence on the purely Greek nature of the Archaic-Classical cult of Zeus Meilichios makes him loathe to admit any evidence of Punic or indigenous influence in the "sacred area." 120

\section{The stratigraphy of the Field of Stelae}

At some point after ca. 500 BC, the Field of Stelae was raised by an earth embankment, on which the Meilichios precinct and the Punic style naïskos were built. Scholars have dated this building operation variously, from the sixth to the third century. ${ }^{121}$ Whenever this levelling took place, the stelae and the associated deposits from the northern corner of the Field of Stelae would have been mixed together helter-skelter and covered by the earth fill, which helps to explain Gabrici's difficulty in determining the stratigraphy. Grotta transcribes relevant parts of Gabrici's Giornali di Scavi, to illuminate the problem. ${ }^{122}$ He concludes that the building of the embankment had "obliterated" all evidence of the earlier use of the northern corner of the sanctuary. The twin stelae found in the Meilichios precinct “... were not fixed in the ground ... [nor] associated with sacrificial remains or votive deposits of any kind ...” 123

117 Grotta (2010), 23-37, 45: "The term campo di stele evokes ... the mystery of the Tophet of Carthage ...”

118 Jameson et al. (1993), 89-91; Grotta (2010), 101-136.

119 Grotta (2010), 46.

120 Grotta (2010), 221-232.

121 At the end of the sixth century: Dewailly (1992), 37. In the fourth century or later: White (1967), 349; Famà and Tusa (2000), 12. In the early third century: Grotta (2010), 221-223; cf. Riotto (1985), 36; Jameson, et al. (1993), 134; C. Marconi, Personal Communication, February 6, 2019.

122 Grotta (2010), Appendix 1, 252-276; also, Dewailly (1992), 36-40

123 Grotta (2010), 95. 
This last statement is contradicted by Gabrici's published and unpublished descriptions of the stelae's find-spots. According to Gabrici, some sixty votive stelae, aniconic, one-headed, and two-headed, were found in and around the Meilichios precinct. Some of the stelae were mixed in with the earthen fill used to raise the floor level, but at least ten stelae were found two meters below the present ground level, set upright on a blackish ancient surface, presumably in situ. At least ten deposits of burnt animal bones, burnt miniature vases, broken pottery, figurines and ashes are identified at the bases of votive stelae. ${ }^{124}$

Grotta hypothesizes that Gabrici "found a pit in which these specimens [the twin stelae] had been discarded", before the raising of the level of the precinct. ${ }^{125} \mathrm{He}$ concludes: "The single, double and quadruple stelae, all uninscribed and all found inside the precinct, represent a real archaeological mystery; reading the excavation journals allows us to rule out that they came from the 'field of stelae' ..." ${ }^{126}$ However, the two-headed stelae were not all found together in a supposed waste pit beneath the Meilichios precinct. Gabrici's excavation journals detail at least seven different findspots: west of the naïskos, west of the precinct wall, high on the slope of the Field of Stelae, inside the naïskos, in front of the naïskos, near the naïskos, and in the northeast angle of the naïskos (Fig. 17). ${ }^{127}$

124 Grotta (2010), Appendix 1, 252, 258, 275.

125 Grotta (2010), 95-96.

126 Grotta (2010), 231.

127 Grotta (2010), Appendix 1, 252-276. 




Fig. 17: Drawing of Meilichios precinct with findspots of twin stelae, as noted in Gabrici's excavation journals. After Gabrici (1927), Pl. 2.

Only twenty-five of Famà's sixty-four two-headed stelae are recorded in Gabrici's excavation journals, however; the provenance of the others is unclear. ${ }^{128}$ It cannot be ruled out that some came from the Field of Stelae, or from the surface of the older Field of Stelae beneath the Meilichios precinct. Some of the stelae from the fill beneath the Meilichios precinct could be fifth century or earlier. An example is the sandstone stela inscribed "AINEA $\Sigma$ " which Gabrici found near the naïskos at the same depth as the twin stelae. ${ }^{129}$ This stone is dated to the late sixth century by its lettering, ${ }^{130}$ which makes it possible that the twin stelae at the same level were dedicated in the same period.

128 \#1108-1129, 1134-1136 in Gabrici’s journals: Grotta (2010), Appendix 1, $272-274$.

129 Grotta (2010), Appendix 1, 276 (21-31 May, 1922).

130 Jameson, et al. (1993), 90(h). 
In sum, despite the absence of a clear stratigraphy, it is possible to agree with Famà that the twin stelae were deposited from the sixth to the fourth centuries, ${ }^{131}$ on the following grounds: 1). Those stelae found beneath the naïskos, even if carved in a fourth-century Punic style, should be earlier than 409 BC. ${ }^{132}$ 2). Some of the twin stelae were found as much as two meters beneath the present surface, set upright in a "hearth" of ash, burnt bones and broken pottery; they could have been in situ. ${ }^{133} 3$ ). The inscribed Meilichios stones, which have been dated to the sixth and fifth centuries on the basis of lettering and dialect, ${ }^{134}$ were deposited in the same areas and at the same depth as the twin stelae. 4). Stelae similar in style and fabric, also deposited in a "hearth" of ashes, burnt bones and pottery, were excavated in 1969-1970, and were dated by accompanying pottery to the sixth and fifth centuries. ${ }^{135}$

It is clear that the twin stelae cannot all be post 409 BC. Many must have been dedicated in the northern corner of the sanctuary area before the building of the embankment and the Meilichios precinct after ca. 500. The later surface level would have continued to be used as a Field of Stelae. The twin stelae may indeed represent some sort of Greco-Punic religious fusion, as has been argued. ${ }^{136}$

\section{The identity of the deities}

That the twin stelae represent deities and are not funerary markers is well accepted and gains credibility from the fact that the sanctuary area is neither a cemetery nor a tophet. The only bodies burned here are those of the small sacrificial animals (birds, mice etc.), which were apparently deposited with the stelae. ${ }^{137}$

Many scholars have suggested names for this divine couple, beginning with Gabrici, who saw the deities as Zeus Meilichios or Hades, and his Queen as Kore/ Persephone or Pasikrateia. ${ }^{138}$ Later theories suggest that they were generic Medi-

\footnotetext{
131 Famà and Tusa (2000), 32.

132 White (1967), 349.

133 Grotta (2010), Appendix 1, 252.

134 Jameson, et al. (1993), 89-91

135 V. Tusa, et al. (1984), 14 and n. 4; Dehl and Dewailly (1986), 66.

136 Jameson, et al. (1993), 137-141.

137 Bergquist (1992), 45-46; Famà and Tusa (2000), 11.

138 Gabrici (1927), 175; di Vita (1961-1964), 237.
} 
terranean deities, known only as Malophoros and Meilichios. ${ }^{139}$ White concluded that the deities were Ba'al Hammon and Tanit, as did V. Tusa. ${ }^{140}$ Jameson, et al. stipulated that the female deity should be Tanit, not Pasikrateia, Kore or Meilichia. ${ }^{141}$ Famà identifies the deities as Zeus Meilichios and Hera/ Pasikrateia. ${ }^{142}$ Despite all these fascinating speculations, there are only three divine names attested epigraphically in the sanctuary area: Demeter Malophoros, Hecate and Zeus Meilichios. Pasikrateia appears in the military-political context of the Temple G inscription, not on the Gaggera hill, nor can she be securely identified with any known Greek goddess. Neither the names of Ba'al and Tanit nor their conventional depictions are found anywhere in Selinus. The most ingenious arguments have failed to establish the names of this divine couple.

Once again we are stumped by the unique nature of these twin stelae. The nameless divinities whose diminutive effigies were dedicated in the Field of Stelae over a period from the late seventh century into the third century cannot be claimed as major gods of the Greek or the Punic pantheon. No Punic or Greek divine pair appear to have any relation to the ritual in which the stelae were employed. The stelae, two-headed, one-headed, or aniconic, were usually set up above a small sacrificial deposit of burnt pottery, burnt small animal bones and figurines, where a private sacrifice was performed by a family or clan group, perhaps in honor of the chthonic ancestors. In style they combine iconographic elements from both cultures, and may include indigenous features as well, as has been argued at some length by Famà. ${ }^{143}$

Some have finely carved features; others are aniconic or semi-iconic. Jameson, et al. have compared the latter to ápyoi $\lambda \dot{i} \theta$ os, unworked stones, supposedly the earliest form in which the Greeks worshipped their gods (Paus. 7.22.4). They characterize the stelae as a "development in popular art ... in the service of private or family cult." 144 This folk cult was expressed in the inexpert carving of local Selinuntines and apparently did not require writing or priestly paraphernalia to empower its rites.

139 Pace (1945), 473-478.

140 White (1967), 351; V. Tusa (1971), 63.

141 Jameson, et al. (1993), 137.

142 Famà and Tusa (2000), 77.

143 Famà and Tusa (2000), 23.

144 Jameson, et al. (1993), 99 n. 21, 101 


\section{Household gods}

I would like to argue that the Selinuntine stelae represent household or family gods, traditional in the Mediterranean world from the Bronze Age down to the Roman period. These small idols of stone or terracotta were regularly honored in a domestic or ancestral cult, whether in a house, a cemetery or a sacred space. They were not the great national gods, but deities of popular or folk cult. The gods who protect the house and family can be simply called "mother" or "father" of the house or they can bear the names of the great national gods. Household or family religion is well attested in ancient sources and has recently inspired new interest among historians of religion and archaeologists. ${ }^{145} \mathrm{~A}$ recent collection of the ancient evidence describes the social role of ancient domestic cult: "The religion of household and family, located primarily in the home and at the family tomb ..." is opposed to "... the religion of public, civic, and state religion epitomized by the temple.” ${ }^{146}$

The Ancient Near East. In Bronze Age Mesopotamia, the "god and goddess of the house," in the form of anthropomorphic stelae or statuettes, received ancestor cult in a shrine in the family home. The ritual was performed by the father, as "invoker of the name," i.e. the family name. As early as the third millennium, the ritual feeding of the ancestors took place at a monthly clan feast in the home. The figurine of "the god of the father" could also be set up in a neighborhood shrine. ${ }^{147}$ The national god might oversee rites invoking the ancestors of the entire town as a group; thus, family cult was integrated with state cult. ${ }^{148}$

Archaeologists searching for the material evidence of this domestic cult in the Ancient Near East have identified the household gods in small figurines of stone or terracotta in domestic shrines and cemeteries. ${ }^{149}$ Figurines or stelae with two heads like the twin stelae from Selinus are harder to find; one of the few comparanda and certainly the earliest are the two headed plaster busts from 'Ain Ghazal, Jordan, dated to $6500 \mathrm{BC}$ (Fig. 18). ${ }^{150}$ Some have argued that these busts represent

145 Holladay (1987); van der Toorn (1996); Daviau (2001); Willett (2002); Swinford (2006); Bodel and Olyan (2008); Albertz and Schmitt (2012).

146 Stowers (2008), 11.

147 Van der Toorn (1996), 50-52, 219-225 and (2008), 21.

148 Fleming (2008), 45; Willett (2002), 31

149 Carter (1970); Stockton (1970); Holladay (1987); Beck (1990); Daviau (2001); Willett (2002); Wiener (2011); Albertz and Schmitt (2012).

150 Rollefson and Simmons (1987), 93-106. 
twin deities; others see ghosts or ancestor gods, evidence of domestic cult. ${ }^{151}$ Parallels to them are found in Anatolia, Mesopotamia and Cyprus as late as the midsecond millennium (Fig. 19). ${ }^{152}$ One may well ask why evidence from the Neolithic and Bronze Ages has any validity for the Iron Age stelae from Selinus. As we will see in what follows, the material remains of traditional household religion are to be found in archaeological contexts from the Bronze Age to the late Roman period everywhere in the Mediterranean world.

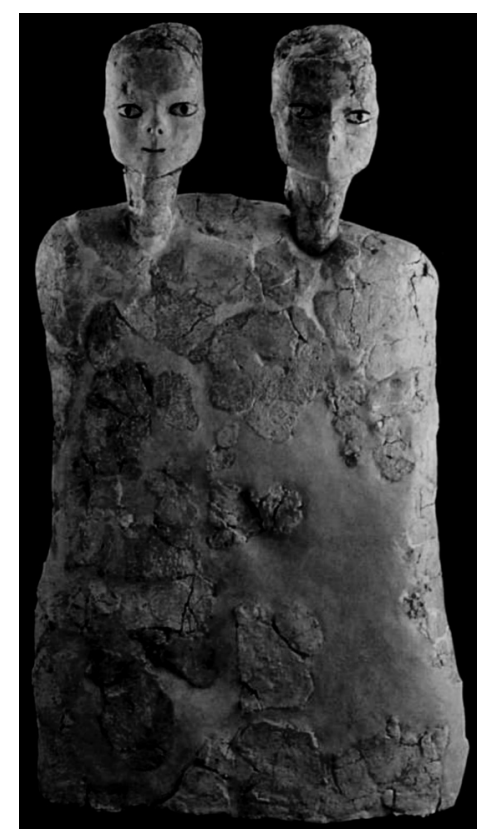

Fig. 18: Two-headed plaster bust from 'Ain Ghazal Jordan, 6500 BC. With permission from the 'Ain Ghazal Archaeological Project. Photo by J. Tsantes.

151 Schmandt-Besserat (1998), 10-12.

152 Schmandt-Besserat (1998), 12, Fig. 11. 




A

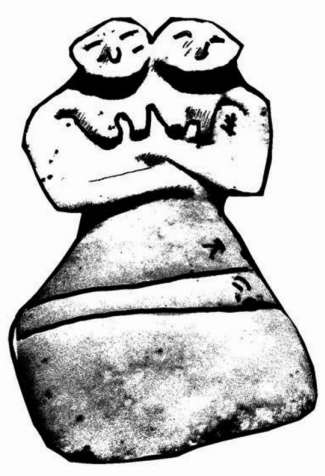

B

Fig. 19: Two-headed "idols:" A. Vase in shape of a couple, Cyprus, 1750 BC (after Karageorghis 1981, Fig. 36). B. Two-headed goddess, Catal Huyuk, 6000 BC (after Mellaart 1967, Fig. 161).

Much more common than two-headed busts are the semi-iconic "stone spirits," found in late Bronze Age Mesopotamia, Syria, Israel, Phoenicia and pre-Islamic Arabia. ${ }^{153}$ These uninscribed figures are found in many contexts, in domestic shrines, neighborhood sanctuaries, workshops and graves (Fig. 20). Their crude appearance and wide distribution as well as their small size (under $30 \mathrm{~cm}$ ) makes it clear that they were not part of state cult, but were personal household gods. Their stylistic similarities underline their international character.
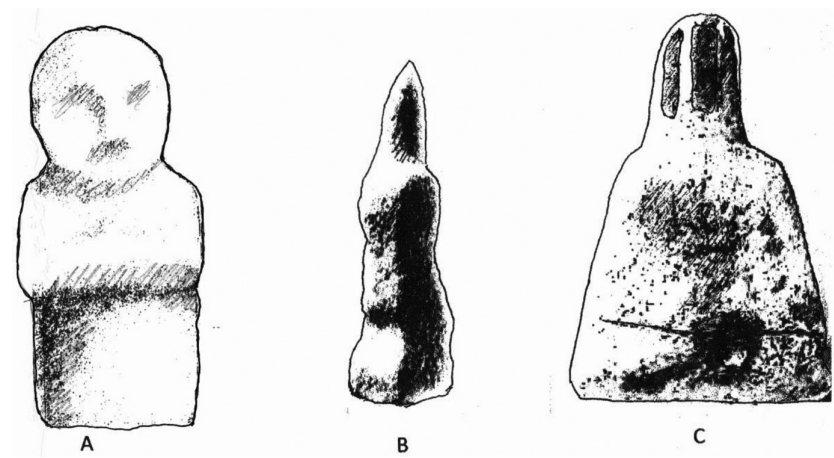

Fig. 20: "Stone spirits: A. Tel Sabi Abyad, Syria, thirteenth to twelfth century BC (after Weiner 2011, 130, \#8), B. Hazor, Israel, thirteenth century. BC (after Beck 1990, 92, Fig. 1). C. Tepe Gawra, Mesopotamia, second millennium BC (Carter 1970, 24, \#2).

153 The phrase "stone spirits" is Carter's (1970). Her catalog and conclusions are expanded by Wiener (2011). 
Like the diminutive stelae from the Meilichios precinct, the stone spirits were a product of popular religion, produced by ordinary unskilled persons, not in craft workshops. Even in cities where skilled sculptors were active, the "stone spirits” were still "homemade," produced by private individuals. ${ }^{154}$

Canaan-Phoenicia. In Bronze Age Ugarit, as in Mesopotamia, it was the filial duty of the oldest son to set up the stela of the "god of the father" in the sanctuary. The family gods were addressed as "father" and "mother," and their worship is evidenced by the many terracotta and precious metal figurines found in domestic contexts. The divine guardians of the Canaanite household were conceived of as the national Lord and Lady, Ba'al and Astarte. ${ }^{155}$ In Phoenician domestic cult as well, the household god could be addressed by the name of a high god of the pantheon. However, when a major deity was assimilated into the domestic cult, he was expected to act as a household god, protecting a particular family. ${ }^{156}$ The worship of such household gods in eastern and western Phoenicia (Carthage) continued into the Hellenistic and Roman period. ${ }^{157}$

Iron Age remains of domestic cult practices in Phoenicia resemble those found in Syria and Israel. In Phoenicia and the Punic world miniature incense altars, associated with cult vessels and statuettes, are found in sanctuaries, tombs and residential areas from the Archaic to the Roman period, and are interpreted as evidence of domestic cult. ${ }^{158}$ The Phoenician tradition of setting up a stela in the sanctuary to represent the ancestor continued even into pre-Islamic Arabia. ${ }^{159}$

Israel. Similar customs prevailed in early Israel, where the teraphim, ancestor figurines employed in household cult, were kept in the house. The ancestors were powerful protectors who had healing powers and could foretell the future. ${ }^{160}$ The teraphim are mentioned frequently in the Bible. In Gen. 31:19-33, Rachel steals her father Laban's teraphim, to give her husband Jacob possession of the ancestral gods. The teraphim must have been small objects, as she was able to conceal them beneath her saddle.

154 Dewailly (1992), 134; Jameson, et al. (1993), 99 n. 21, 101; Famà and Tusa (2000), 19, 26; Willett (2002), 27, 31; Schmitt (2008), 168: Wiener (2011), 28.

155 Lewis (2008), 64-65, 68-9, 79-80; Van der Toorn (1996), 172-173.

156 Willett (2002), 27, 32-33; Albertz and Schmitt (2012), 219, 348.

157 Van der Toorn (1996), 177.

158 Spagnoli (2015), 222-228.

159 Stockton (1970), 77-81.

160 Van der Toorn (1996), 219-225; Albertz and Schmitt (2012), 61. 
A number of small $(20-25 \mathrm{~cm})$ stone statuettes from the Stelae Temple of Hazor have been interpreted as "guardian spirits" or "ancestor idols," similar to Carter's "stone spirits." ${ }^{161}$ From the late Bronze to the Hellenistic period, archaeological evidence for Israelite domestic cult is abundant and includes incense stands, stelae and figurines. Domestic cult included the worship of the goddess Asherah as well as the teraphim. ${ }^{162}$

Egypt. In the third milennium, there is evidence of the worship of ancestor deities and household gods in Egyptian domestic spaces. Shrines with stelae and figurines honored Taweret, goddess of childbirth, Hathor, goddess of fertility, and Bes, protector of children, as well as the ancestors. Even during Akhenaten's monotheistic reforms in the New Kingdom, the cult of the traditional household gods continued in the homes of the common people. ${ }^{163}$

Minoan Crete. Domestic gods protected the house and family already by the Early Minoan period, when small statuettes of the snake-goddess exercised this function, according to Nilsson. ${ }^{164}$ Numerous sites for domestic cult have been found in palaces and houses, from "lustral basins" to bench sanctuaries. Cult paraphernalia found there include cult vessels, offering tables, divine symbols (horns of consecration, double axes), and figurines of worshippers and deities. ${ }^{165}$

Greece. The ancient Greek household gods, like their Near Eastern counterparts, were among the $\pi \alpha \tau \rho \tilde{\omega}$ or $\theta \varepsilon o$, the ancestral gods. ${ }^{166}$ It is argued above that Zeus Meilichios, who purified the family and dealt with malign ghosts, played the role of an ancestral god: his votive reliefs and inscriptions commemorated sacrifices by a family group and his many humble shrines were dedicated to "Zeus Meilichios of the (clan name)." 167 His epiclesis, "he who may be propitiated," gives it away; he is a fearsome chthonic god who protects the wealth and purity of the family lineage. Nevertheless, reliefs dedicated to Zeus Meilichios are most often found in sanctuaries or in public places, not in the family home. ${ }^{168}$

161 Carter (1970), 37; Beck (1990), 91, 94.

162 Holladay (1987), 275; Van der Toorn (1996), 219; Willett (2002), 32-37; Albertz (2008), 97-99; Albertz and Schmitt (2012), 57-219. Zevit (2001), 273 denies that the figurines represent a divine couple.

163 Stevens (2003), 161-164; Lesko (2008), 199-201; Ritner (2008), 181-183.

164 Nilsson (1961), 71.

165 Gesell (1985),143-149; Sikla (2011), 230-231.

166 Parker (2005), 37.

167 Jameson, et al. (1993), 82 e, f.

168 Parker (2005), 46-47. 
Zeus was also worshipped as Ktesios (of property), the guardian of the family's health and wealth: classical sources emphasize the intimate nature of sacrifice to Zeus Ktesios (Isae. 8.15-16; Antiph. 1.15-18). ${ }^{169}$ The family slaves gathered at his altar for safety (Aesch. Ag. 1036-1038). He was represented by a twohandled jar in the household storeroom, decorated with wool fillets and filled with symbols of plenty (Ath. 473b-c; Suda s.v. Kтnoiou $\Delta$ iós). ${ }^{170}$ Zeus Herkeios (of the fence) also guarded the family home and was an essential part of every man's identity as a citizen, as was Apollo Patroos (Dem. 57.67; Arist. [Ath. Pol.] 55.3; Harp. 134). The altar of Zeus Herkeios was set up in the household courtyard

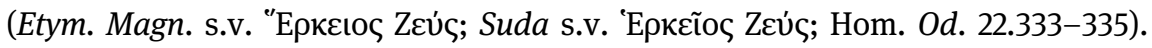
Hestia, virgin goddess of the hearth, played a major role in domestic religion. New members of the family were ritually welcomed at the hearth; Hestia received libations there at family meals. Hestia ensured the purity and prosperity of the family hearth. ${ }^{171}$ As in the Ancient Near East, Greek household deities could also appear in the context of polis religion. ${ }^{172}$ In Athens, Hestia was worshipped in the Pryta-


FGrH 328 F67). Apollo Patroos was the ancestor of all Ionians as well as the protector of each lineage (Dem. 57.67).

Our knowledge of ancient Greek household religion comes almost entirely from literary or epigraphical sources. ${ }^{173}$ The archaeological evidence is limited to the remains of hearths, altars, water-basins and incense-burners. These furnishings, whether built-in and permanent or small and portable, could have more than one function. The hearth was used for cooking, and the water-basin, when not employed in purification rituals, could also be used for taking a bath. On the other hand, it is difficult to imagine non-cultic uses for altars and incense-burners. ${ }^{174} \mathrm{~A}$ number of small household shrines, called 'stele shrines' have been found in fourth century B.C. Corinth, rare examples of cult objects (altars, figurines) found together in a Greek household shrine. ${ }^{175}$ Even in the absence of substantial material evidence, the ubiquity of household cult is demonstrated by the fact that Plato considered it desirable to legislate against it, ruling that, in his ideal city, "no one is to set up shrines of the gods in a private house" (Leg. 909d-910b).

169 Boedeker (2008), 230-231.

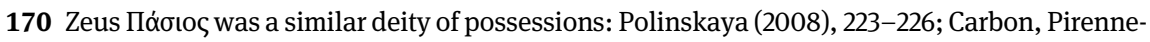
Delforge (2013), 76, 96.

171 Parker (2005), 13-14; Boedeker (2008), 234; Mikalson (2010), 125.

172 Faraone (2008), 216-217.

173 Morgan (2007); Parker (2015).

174 Swinford (2006), 45-49.

175 Williams (1981), 419-420 and Fig. 3. See, however, A. F. Ward, (2018). 




Fig. 21: Lararium, Pompeii, first century AD. After Bodel (2008), 256, fig. 14.2a.

Rome. The Roman family religion centered around the Lares and Penates, the ancestral spirits who guarded the family and its prosperity and were kept in the family Lararium. The Lares familiares, the ancestors, were particularly the focus of the devotion of the household slaves, in an interesting parallel to the protection of slaves by Zeus Ktesios. A wall painting from Pompeii shows two Lares in human form on either side of the genius of the householder, who performs a sacrifice. Below, two large snakes receive offerings on an altar (Fig. 21). Comparison with the household snake associated with Zeus Meilichios or Ktesios gives us a clue as to the meaning of these reptilian symbols of agricultural fertility and the underworld. The snake is relevant both to the ancestors and the pantry.

\section{Conclusion}

The most important distinction between the twin stelae from Selinus and the many other effigies of household gods discussed here is the two heads or busts atop the Selinuntine stelae. It could be argued, as do Jameson, et al. (1993), that 
the feminine element of the divine couple is an innovation resulting from the colonial situation; they note that a number of Meilichios stones were dedicated by women; this is "another indication of the largely private character of the cult."176 In both the Greek and Near Eastern tradition heavy emphasis is placed on the male ancestral line; the Phoenician dedicator "sets up the marker of his father," and the Greek householder proves his citizen status by his possession of an Apollo Patroos. ${ }^{177}$ The appearance of the household gods as a couple may be an innovation unique to Selinus, as was the syncretistic iconography employed by their local creators. The twin stelae are a colonial development, the result of a mixture of cultures in the "middle ground" of far southwestern Sicily, in a new city founded amidst the settlements of Greeks, Elymians and Phoenicians.

Who were the deities on these stelae? It is clear enough from the stratigraphic evidence of Gabrici's journals, and from the stylistically very similar (even if not twin) stelae excavated beginning in 1969, that the twin stelae were dedicated over a long period from the seventh to the third century. Their remarkable mixture of styles and the wide range of dates attributed to them indicates an origin that is not merely Greek or Punic or Elymian, but a mixture of all three, as Famà has painstakingly established. ${ }^{178}$ We cannot give them the names of great national gods such as Ba'al and Tanit or Zeus and Hera; we would be more prudent to recognize that they represent the "gods of the house." "This identification of the twin stelae from Selinus as household gods leaves them still anonymous, however, with no other names but 'mother' and "father" or $\theta \varepsilon \alpha$ and $\theta \varepsilon$ có. ${ }^{180}$

We can only imagine how important these little ancestral gods were to the different groups who settled in Selinus from the seventh century on. Even though the colonists brought with them their fully developed civic cults from the mother city, including gods whose epithets and myths were already familiar, and rites already illuminated by hoary aetiological myths, as well as priests and priestesses from the homeland shrine, nevertheless, they had to leave behind their ancestral graves in the cemetery, that piece of land most symbolic of identity and autochthony in the ancient world.

The recreation of a sacred ancestral topography in a new and unfamiliar landscape depended upon the colonists' ability to ritually summon the support and protection of those household/ancestor gods and to re-install them in a new sacred area. The consecration of and repeated sacrifices to the family gods in the

176 Jameson, et al. (1993), 93.

177 Van der Toorn (1996), 25.

178 Famà and Tusa (2000).

179 Van der Toorn (1996), 172-173.

180 Clinton (1992), 13. 
Field of Stelae at Selinus represent a syncretism of old and new, Greek, Punic and Elymian, foreign and familiar. The Selinuntine colonists all brought traditions from their homes, whether Tyre or Motya, Corinth or Megara, Segesta or Entella; but they also adopted artistic forms and traditions from their new neighbors to create culture and cult distinctive to their new home. ${ }^{181}$

The twin stelae are apparently unique: they are not strictly Greek, Punic, or Elymian in style. They do not represent the deities of a highly visible and articulated pantheon, the great national gods maintained by the state; rather, they represent the family religion that seems to have been ubiquitous in the ancient Mediterranean. Each of the Selinuntine stelae embodies the genii or spirits of a particular family lineage. Cult must be paid to such deities on a regular basis to ensure their protection of the prosperity and fecundity of the household and its continuation from generation to generation.

Acknowledgment: I would like to thank Alan Shapiro, Anthony Spawforth and Clemente Marconi for their incisive comments on this essay.

\section{Bibliography}

Albertz, R. "Family religion in ancient Israel and its surroundings." In Bodel and Olyan 2008, 89-112.

Albertz, R. and R. Schmitt. Family and Household Religion in Ancient Israel and the Levant. Winona Lake: Eisenbrauns, 2012.

Aubet, M.A. The Phoenicians and the West: politics, colonies and trade. Second Edition. New York: Cambridge U. P., 2001.

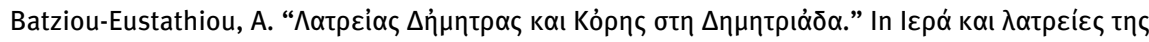


Greek World), edited by I. Leventi and C. Mitsopoulou, 179-199. Volos, Greece: University of Thessaly, 2010.

Beck, P. "A note on the 'schematic statues' from the Stelae Temple at Hazor.” Tel Aviv 17 (1990): 91-95.

Bergquist, B. "A particular western Greek cult practice? The significance of stele-crowned, sacrificial deposits." Opuscula Atheniensia 19 (1992): 41-47.

Bisi, A. M. Le Stele Puniche. Studi Semitici 27. Rome: Istituto di studi del vicino Oriente, Università, 1967.

Bodel, J. "Cicero's Minerva, Penates and the mother of the Lares: an outline of Roman domestic religion." In Bodel and Olyan 2008, 248-275.

Bodel, J. and S. M. Olyan, editors. Household and Family Religion in Antiquity. Malden: Blackwell, 2008.

181 Antonetti and De Vido (2006), 425-427. 
Boedeker, D. “Family matters: domestic religion in Classical Greece.” In Bodel and Olyan 2008, 229-247.

Bonnet, C. "Greeks and Phoenicians in the western Mediterranean." In A Companion to Ethnicity in the Ancient Mediterranean, edited by J. McInerney, 327-340. Malden, MA: Wiley-Blackwell, 2014.

Brown, S. Late Carthaginian Child Sacrifice and Sacrificial Monuments in their Mediterranean Context. JSOT/ASOR Monograph Ser. 3, Sheffield: Sheffield Academic, 1991.

Burkert, W. Greek Religion. Translated by J. Raffan. Cambridge: Harvard U. P., 1985.

Burton, D. "Hades, cornucopiae, fertility and death." Australasian Society for Classical Studies Proceedings 32 (2011): 1-7.

Carbon, J.-M. and V. Pirenne-Delforge. "Priests and cult personnel in three Hellenistic families." In Cities and Priests. Cult personnel in Asia Minor and the Aegean islands from the Hellenistic to the Imperial period, edited by M. Horster, and A. Klöckner, 65-119. Berlin: De Gruyter, 2013.

Carter, T. H. “The stone spirits." Expedition 12 (1970): 22-40.

Cartledge, P. The Greeks: a portrait of self and others. Oxford: Oxford U. P. 2002.

Chiarenza-Roma, N. “Nota su un Altare a Tre Betili a Selinunte.” Vicino Oriente 13 (2007): 177-196.

Cintas, P. “La Sanctuaire Punique de Sousse.” Revue Africaine 91 (1947):1-80.

Clinton, K. Myth and Cult. The iconography of the Eleusinian Mysteries. Stockholm: Svenska Institutet I Athen, 1992.

Clinton, K. “A new Lex Sacra from Selinous: kindly Zeuses, Eumenides, impure and pure Tritopatores and Elasteroi." CPh 91 (1996): 159-179.

Collin-Bouffier, S. "Parentés et spécificités culturelles en Sicile grecque à travers les tablettes de malediction." In Alleanze e parentele. Le 'affinità elettive' nella storiografia sulla Sicilia antica, 14-15, edited by D. Bonanno, et al., 89-112. Caltanisetta-Rome: Salvatore Sciascia, 2010.

Cordano, F. "La Malophoros, particolare dea dei Megaresi." Culti e Miti Greci in Aree Periferiche. Aristonothos 6 (2012): 169-177.

Cross, A. “Child sacrifice at the Tophet." MA Thesis. Hebrew University, 2012.

Daviau, P. M. M. "Family religion: evidence for the paraphernalia of the domestic cult." In The World of the Aramaeans II. Studies in History and Archaeology. JSOTSup 325, edited by P. M. M. Daviau, J. W. Wevers and M. Weigl, 199-229. Sheffield: Sheffield Academic, 2001.

Day, J. "Molech: a god of human sacrifice in the Old Testament." University of Cambridge Oriental Publications 41. Cambridge: Cambridge U. P., 1989.

De Angelis, F. "The foundation of Selinous: overpopulation or opportunities?" In The Archaeology of Greek Colonization: essays dedicated to Sir John Boardman, edited by G. Tsetskhladze and F. de Angelis, 87-110. Oxford: Oxford U. P., 1994.

De Angelis, F. Megara Hyblaea and Selinous. The development of two Greek city-states in Archaic Sicily. Oxford: Oxford U. P., 2003a.

De Angelis, F. "Equations of culture: the meeting of natives and Greeks in Sicily (ca. 750-450 BC)." In Ancient Greeks West and East II, edited by G. R. Tsetskhladze, 19-50. Leiden: Brill, 2003b.

De Angelis, F. “Archaeology in Sicily 2006-2010.” ArchRep 58 (2012): 123-195.

Dehl, C. and M. DeWailly. “Area Muro-Nord.” In Tusa, S., et al., "Selinunte-Malophoros. Rapporto preliminare sulla II campagna di scavi.” SicArch 19 (1986): 59-66. 
De Simone, R. “Selinunte Punica." In Selinunte, edited by S. Tusa, 181-190. Roma: Bretschneider, 2010.

Dewailly, M. Les statuettes aux parures du sanctuaire de la Malophoros à Sélinonte: contexte, typologie et interprétation d'une catégorie d'offrandes. Naples: Cahiers du Centre Jean Bérard 17, 1992.

Di Vita, A. “Le stele puniche dal recinto di Zeus Meilichios a Selinunte." Accademia etrusca di Cortona. Annuario 12, n. s. 5 (1961-1964): 235-250.

Dussaud, R. “Melqart.” Syria 25 (1946): 205-230.

Famà, M. L. "L’area sacra con altare 'a tre betili’ di Solunto.” SicArch 13 (1980): 7-42.

Famà, M. L. and V. Tusa. Le stele del Meilichios di Selinunte. Padova: Bottega D’Erasmo, 2000.

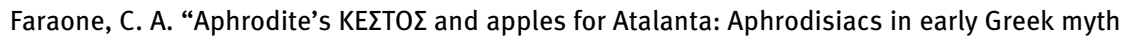
and ritual." Phoenix 44 (1990): 219-243.

Faraone, C. A. "Household religion in ancient Greece.” In Bodel and Olyan 2008, 210-228.

Farnell L. R. Cults of the Greek States. Volume 3. Oxford: Oxford U. P., 1907.

Fischer-Hansen T., T. H. Nielsen and C. Ampolo. s.v. "Selinous." In An Inventory of Archaic and Classical Poleis, edited by M. H. Hansen and T. H. Nielsen, 220-224. Oxford: Oxford U. P., 2004.

Fleming, D. "The integration of household and community religion in ancient Syria." In Bodel and Olyan 2008, 37-59.

Foxhall, L. "Cultures, landscapes and identities." In Mediterranean Paradigms and Classical Antiquity, edited by I. Malkin, 75-92. New York: Routledge, 2005.

Foucart, P. “Meilichios et Milichios.” In Dar.-Sag. 3. (1904): 1700.

Gabrici, E. Il Santuario della Malophoros a Selinunte. Mon. Ant. 32. Milano: Ulrico Hoepli 1927. Reprinted, Mainz: Philipp von Zabern, 1971.

Gaifman, M. Aniconism in Greek Antiquity. Oxford: Oxford U. P., 2012.

Gesell, G. C. Town, Palace, and House Cult in Minoan Crete. Goteborg: Åström, 1985.

Gourmelen, L. "Le serpent barbu: réalités, croyances et représentations. L'exemple de Zeus Meilichios à Athènes."Anthropozoologica 47 (2012): 323-343.

Graf, F. and S. I. Johnston. Ritual Texts for the Afterlife. Orpheus and the Bacchic gold tablets. London: Routledge, 2007.

Grotta, C. Zeus Meilichios a Selinunte. Historica 9. Rome: Bretschneider, 2010.

Hadzisteliou-Price, T. "Double and multiple representations in Greek art and religious thought." JHS 91 (1971): 48-69.

Heider, G. C. The Cult of Molek: a reassessment. JSOTSup 43. Sheffield: Sheffield U. P., 1985.

Hodos, T. Local Responses to Colonization in the Iron Age Mediterranean. London: Routledge, 2006.

Holladay, J. S. "Religion in Israel and Judah under the monarchy: an explicitly archaeological approach." In Ancient Israelite Religion: essays in honor of Frank Moore Cross, edited by P. D. Miller, P. D. Hanson, and S. D. McBride, 249-299. Philadelphia: Fortress, 1987.

Horden, P. and N. Purcell. The Corrupting Sea: a study of Mediterranean history. Volume 1. Oxford: Blackwell, 2000.

Hornblower, S. A Commentary on Thucydides. Volume 3. Oxford: Oxford U. P., 2008.

Jameson, M. H. "Notes on the sacrificial calendar from Erchia." BCH 89 (1965): 154-172.

Jameson, M. H., D. Jordan and R. Kotansky. A Lex Sacra from Selinous. Greek, Roman, and Byzantine Monographs 11. Durham: Duke U. P., 1993.

Karageorghis, V. Ancient Cyprus. 7,000 years of art and archaeology. Baton Rouge: Louisiana State U. P., 1981. 
Lalonde, G. V. Horos Dios: an Athenian shrine and cult of Zeus. Leiden: Brill, 2006.

Lesko, B. S. "Household and domestic religion in ancient Egypt.” In Bodel and Olyan 2008, 197-209.

Lewis T. J. "Family, household and local religion at late Bronze Age Ugarit.” In Bodel and Olyan 2008, 60-88.

Lipinski, E. “Dieux de Sarepta: Tannit.” Dieux et Déesses de l'univers Phenicien et Punique. StPhoen 14 (1995): 199-215.

Malkin, I. Religion and Colonization in Ancient Greece. Leiden: Brill, 1987.

Malkin, I. A Small Greek World: networks in the ancient Mediterranean. Oxford: Oxford U. P., 2011.

Malkin, I. "Networks and the emergence of Greek identity." Mediterranean Paradigms and Classical Antiquity, edited by I. Malkin, 56-74. New York: Routledge, 2013.

Mantzoulinou-Richards, E. "Demeter Malophoros, the divine sheep-bringer." Ancient World 13 (1986): 15-22.

Marconi, C. "Le attività dell'Institute of Fine Arts - NYU sull'Acropoli di Selinunte (2006-2010)." In Sicilia occidentale. Studi, rassegne, ricerche, edited by C. Ampolo, 279-286. Pisa: Edizioni Della Normale, 2009.

Marconi, C. Temple Decoration and Cultural Identity in the Archaic Greek World: the metopes of Selinus. Cambridge: Cambridge U. P., 2007.

Marconi, C. "Il rilievo con il ratto di Persephone dal Santuario della Malophoros." In Temi Selinuntini, edited by C. Antonetti and S. De Vido, 193-209. Pisa: Edizioni ETS, 2009.

Marconi, C. "Selinunte, City of Sanctuaries." Current World Archaeology 56 (2012): 20-26.

Marconi, C. "Summary of excavation results, 2014." In IFA Excavations at Selinunte. https://www. nyu.edu/gsas/dept/fineart/academics/selinunte/selinunte-report-2014.htm

Marconi, C., V. Tardo and C. Trombi. "The Archaic pottery from the Institute of Fine Arts excavations in the main urban sanctuary on the Acropolis of Selinunte." In Sanctuaries and the Power of Consumption. Networking and the formation of elites in the Archaic western Mediterranean world. Philippika 92, edited by E. Kistler, et al., 325-338. Wiesbaden: Harrassowitz, 2015.

Mellaart, J. Catal Huyuk: a Neolithic town in Anatolia. New York: Thames and Hudson, 1967.

Mikalson, J. D. Ancient Greek Religion. Second edition. Malden, MA: Wiley-Blackwell, 2010.

Miles, M. M. "The propylon to the Sanctuary of Demeter Malophoros at Selinous." AJA 102 (1998): 35-57.

Morakis, A. "Thucydides and the character of Greek colonization in Sicily." CQ 61 (2011): 460-492.

Morgan, J. "Space and the notion of final frontier: searching for ritual boundaries in the Athenian Home." Kernos 20 (2007): 113-129.

Morris, I. "Stanford U. Excavations on Monte Polizzo; report on 2000." Memoirs of the American Academy in Rome 46 (2001): 253-271.

Morris, I. "Mediterraneanization." In Mediterranean Paradigms and Classical Antiquity, edited by I. Malkin, 30-55. New York: Routledge, 2005.

Morris, S. P. "Close encounters on Sicily: Molech, Meilichios, and religious convergence at Selinus." In Religious Convergence in the Ancient Mediterranean. Studies in Ancient Mediterranean Religions 2, edited by S. Blakely and B. J. Collins, 67-89. Atlanta: Lockwood, 2019.

Moscati, S. Italia Archaeologica, Centri greci, punichi, etrusci, italici. Novara: De Agostini Editore, 1973. 
Niemeyer, H. G. "Phoenicians in the Mediterranean. Between expansion and colonisation: a nonGreek model of overseas settlement and presence." In Greek Colonization. An account of Greek colonies and other settlements overseas. Volume 2, edited by G. R. Tsetskhladze, 143-168. Leiden: Brill, 2008.

Nilsson, M. P. Greek Folk Religion. New York: Harper, 1961.

Pace, B. Arte e Civiltà della Sicilia antica, III. Cultura e vita religiosa. Città di Castello: Editrice Dante Alighieri, 1945.

Parker, R. Athenian Religion: a history. Oxford: Oxford U. P., 1996

Parker, R. Polytheism and Society at Athens. Oxford: Oxford U. P., 2005.

Parker, R. "Public and private." In A Companion to the Archaeology of Religion in the Ancient World, edited by J. Rüpke and R. Raja, 71-79. Malden: Wiley-Blackwell, 2015.

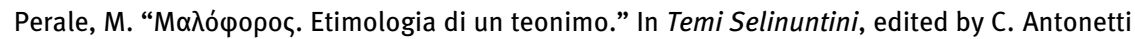
and S. De Vido, 229-244. Pisa: Edizioni ETS, 2009.

Polinskaya, I. "On the Aiginetan cult of Zeus Pasios: a new edition of SEG XI.2." In MIKPO IEP-

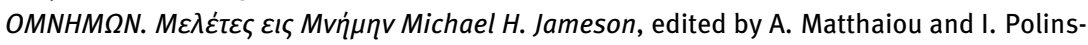
kaya, 211-227. Athens: Hellenic Epigraphical Society, 2008

Posamentir, R. Chersonesan Studies 1: the polychrome grave stelai from the early Hellenistic necropolis. Austin: University of Texas, 2010.

Reynolds, III, B. H. "Molek: dead or alive? The meaning and derivation of mlk and מלב." In Human Sacrifice in Jewish and Christian Tradition, edited by K. Finsterbusch, A. Lange, and D. Römheld, 133-150. Leiden: Brill, 2007.

Riotto, M. “Il Santuario della Malophoros a Selinunte: spunti per una discussione storico-religiosa." SicArch 18 (1985): 25-51.

Ritner, R. K. “Household religion in ancient Egypt.” In Bodel and Olyan 2008, 171-196.

Robu, A. "Le culte de Zeus Meilichios à Sélinonte et la place des groupements familiaux et pseudo-familiaux dans la colonisation mégarienne." In La norme en matière religieuse en Grèce ancienne. Actes du XIe colloque du CIERGA (Rennes 2007). Kernos Supplement 21, edited by P. Brulé, 277-291. Liège: CIERGA, 2009.

Robu, A. "Les fondations mégariennes de Sicile: origine des colons et appropriation du territoire." Cahiers Mondes Anciens 2 (2011): 2-15.

Rollefson, G. O. and A. H. Simmons. "The Neolithic village of 'Ain Ghazal, Jordan: preliminary report on the 1985 season." Bulletin of the American Schools of Oriental Research. Supplement 25 (1987): 93-106.

Schmandt-Besserat, D. “'Ain Ghazal 'monumental' figures.” Bulletin of the American Schools of Oriental Research 310 (1998): 1-17.

Schmitt, R. "Ashdod and the material remains of domestic cults in the Philistine coastal plain." In Bodel and Olyan 2008, 159-170.

Schmitz, P. C. "Review of La civilisation phénicienne et punique: manuel de recherche by Véronique Krings." Journal of the American Oriental Society 121 (2001): 623-636.

Shaw, J. "Phoenicians in southern Crete." AJA 93 (1989): 165-183.

Sikla, E. "The elusive domestic shrine in Neopalatial Crete: on the archaeological correlates of domestic religion." ITETA: the Archaeology of Houses and Households in Ancient Crete. Hesperia Supplement 44 (2011): 219-231.

Sourvinou-Inwood, C. "Persephone and Aphrodite at Locri: a model for personality definition." JHS 98 (1978): 101-121.

Spagnoli, F. “Altari punici nei santuari della Sicilia occidentale.” SicArch 101 (2003): 169191. 
Spagnoli, F. "In the nostrils of God: stone incense altars in Phoenician cult contexts." In Cult and Ritual on the Levantine Coast and Its Impact on the Eastern Mediterranean Realm. Proceedings of the International Symposium, Beirut 2012 (BAAL, Hors-Série X), edited by A. M. Maila-Afeiche, 215-234. Beirut: Phoibos, 2015.

Stager, L. P. "The rite of child sacrifice at ancient Carthage." In New Light on Ancient Carthage, edited by J. Pedley, 1-11. Ann Arbor: University of Michigan, 1980.

Stager, L. P. and P. Wolff. "Child sacrifice at Carthage.” BAR 10 (1984): 31-51.

Stager, L. P., G. Smith, G. Avishai and J. A. Greene. "Aging cremated infants: the problem of sacrifice at the Tophet of Carthage." Antiquity 85 (2011): 859-87.

Stevens, A. "The material evidence for domestic religion at Amarna and preliminary remarks on its interpretation." Journal of Egyptian Archaeology 89 (2003): 143-168.

Stockton, E. D. "Stones at worship." Australian Journal of Biblical Archaeology 1 (1970): 58-81.

Stowers, S. K. "Theorizing ancient household religion." In Bodel and Olyan 2008, 5-19.

Swinford, K. M. The Semi-Fixed Nature of Greek Domestic Religion. M.A. thesis. University of Cincinnati, 2006.

Trümpy, C. Untersuchungen zu den altgriechischen Monatsnamen und Monatsfolgen. Heidelberg: Universitätsverlag C. Winter, 1997.

Tusa, S. “Presenze indigene nel territorio selinuntino." SicArch 15 (1982): 111-118.

Tusa, S., et al., "Selinunte - Malophoros rapporto preliminare sulla II campagna di scavi." SicArch 19 (1986): 13-96.

Tusa, V. “Selinunte punica." Rivista dell'Instituto Nazionale di Archeologia e Storia dell'Arte n. s. 18 (1971): 47-68.

Tusa, V. “Segni di Tanit a Selinonte." Revue de Universidad Complutense 25 (1976): 29-35.

Tusa, V., et al. "Sulla 'Missione Malophoros' Selinunte - Malophoros. Rapporto preliminare sulla I campagna di scavi, 1982." SicArch 17 (1984): 5-66.

Usener, H. Götternamen. Versuch einer Lehre von der religiösen Begriffsbildung. Bonn: F. Cohen, 1896.

Van der Toorn, K. Family Religion in Babylonia, Syria and Israel: continuity and change in the forms of religious life. Leiden: Brill, 1996.

Van der Toorn, K. "Family religion in 2nd milennium west Asia (Mesopotamia, Emar, Nuzi)." In Bodel and Olyan 2008, 20-36.

Van Dommelen, P. and M. Lopez-Bertran. "Hellenism as subaltern practice: rural cults in the Punic world." In The Hellenistic West, edited by J. R. W. Prag and J. C. Quinn, 273-299. Cambridge: Cambridge U. P., 2013.

Ward, A. F. "The stelai shrines of Greek Corinth: new approaches and evidence." Poster session. Annual Meeting of the Archaeological Institute of America, Boston, January 2018.

Ward, C. "Pomegranates in eastern Mediterranean contexts during the late Bronze Age." World Archaeology 34 (2003): 529-541.

White, D. "The post-Classical cult of Malophoros at Selinus." AJA 71 (1967): 335-352.

Whittaker, C. R. “The western Phoenicians: colonization and assimilation." PCPS 200, n. s. 20 (1974): 58-79.

Wiener, N. Damaged Representations: the figurines from Bronze Age Tell Sabi Abyad, Syria and the archaeology of disregard. M.A. thesis. Leiden University, 2011.

Willett, E. A. R. "Infant mortality and family religion in the Biblical period." Davar Logos: Revista Biblico-teologico 1 (2002): 27-42.

Williams, II, C. K. “The city of Corinth and its domestic religion." Hesperia 50 (1981): 408-421. 
Xella, P. “'Divinités doubles' dans le monde phénico-punique.” Semitica 39 (1990): 167-175. Xella, P., J. Quinn, V. Melchiorri and P. van Dommelen. "Phoenician bones of contention.” Antiquity 87 (2013): 1-9.

Zevit, Z. The Religions of Ancient Israel: a synthesis of parallactic approaches. London: Continuum, 2001. 